\title{
Assessing The Long- and Short-Run Asymmetrical Effects of Climate Change On Rice Production: Empirical Evidence From India
}

Imran Ali Baig

AMU: Aligarh Muslim University

Abbas Ali Chandio ( $\square$ alichandio@sicau.edu.cn )

Sichuan Agricultural University https://orcid.org/0000-0001-8706-9681

Ilhan Ozturk

Cag University: Cag Universitesi

Pushp Kumar

IIT Bhubaneswar: Indian Institute of Technology Bhubaneswar

\section{Zeeshan Anis Khan}

AMU: Aligarh Muslim University

Md. Abdus Salam

AMU: Aligarh Muslim University

\section{Research Article}

Keywords: Asymmetry, Granger Causality, India, NARDL, Rice Production

Posted Date: October 1st, 2021

DOI: https://doi.org/10.21203/rs.3.rs-893202/v1

License: () (1) This work is licensed under a Creative Commons Attribution 4.0 International License. Read Full License

Version of Record: A version of this preprint was published at Environmental Science and Pollution Research on January 16th, 2022. See the published version at https://doi.org/10.1007/s11356-02118014-z. 
Assessing the long- and short-run asymmetrical effects of climate change on rice production: Empirical evidence from India

Imran Ali Baig1

${ }^{1}$ Department of Economics, Aligarh Muslim University, Aligarh, India Email: ialibaig043@gmail.com

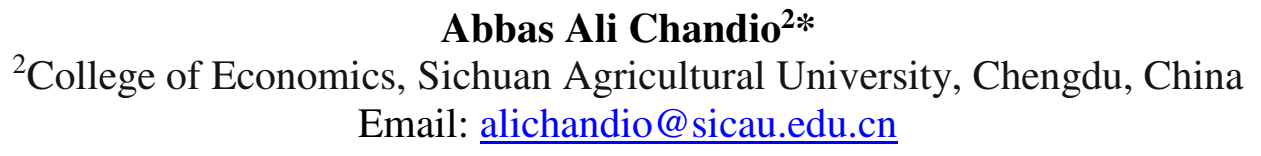

Abbas Ali Chandio ${ }^{2 *}$

${ }^{2}$ College of Economics, Sichuan Agricultural University, Chengdu, China Email: alichandio@sicau.edu.cn

Ilhan Ozturk ${ }^{3 * *}$

${ }^{3}$ Faculty of Economics and Administrative Sciences, Cag University, 33800 Mersin, Turkey

Email: ilhanozturk@cag.edu.tr

Pushp Kumar ${ }^{4}$

${ }^{4}$ Indian Institute of Technology, Bhubaneshwar, India

Email: pk27@iitbbs.ac.in

\section{Zeeshan Anis Khan ${ }^{1}$}

${ }^{1}$ Department of Economics, Aligarh Muslim University, Aligarh, India

Email: zeeshananiskhan@gmail.com

Md. Abdus Salam ${ }^{1}$

${ }^{1}$ Department of Economics, Aligarh Muslim University, Aligarh, India

Email: salam9@gmail.com

*Corresponding author: Email addresses: alichandio@sicau.edu.cn (A. A. Chandio) **Corresponding author: Email: ilhanozturk@ cag.edu.tr (O. Ilhan) 


\section{Abstract}

37 For a couple of decades, environmental change has arisen as a ubiquitous problem and gained environmentalist's attention across the globe due to its long-term harmful effect on agricultural production, food supply, water supply and livelihoods of rural poor. The primary objective of this

40 study is to explore the asymmetrical dynamic relationship between climate change and production

41 of rice and controlled variables covering 1991-2018 by employing the nonlinear autoregressive 42 distributed lag (NARDL) model and Granger causality approach.in India. The NARDL findings 43 demonstrate a significant negative relationship between mean temperature and production of rice 44 in the long run while positively influencing rice production in the short run. Moreover, positive 45 shocks in rainfall and carbon emission have a negative and significant effect on India's rice 46 production in the long and short run. In comparison, negative shock in rainfall has a significant 47 positive impact on rice production in the long and short run. Wald test confirms the asymmetrical relationship between climate change and rice production. The Granger causality test shows 49 feedback effect among mean temperature, decreasing rainfall, increasing carbon emission, and rice 50 production. While no causal relationship between increasing temperature and decreasing carbon 51 emission. Based on our empirical investigations, some critical policy implications emerged. To 52 sustain rice production, improve irrigation infrastructure through increasing public investment and 53 develop climate-resilient seeds varieties to cope with climate change. Along with, at the district 54 level government should provide proper training to farmers regarding the usage of pesticides, 55 proper amount of fertiliser and irrigation systems.

56 Keywords: Asymmetry, Granger Causality, India, NARDL, Rice Production 


\section{Introduction}

58 Due to the long-term adverse effect on agricultural productivity, food production, water availability, and rural lives, climate change has garnered environmentalist and policymaker attention across the globe since 1990s ( Chavas et al. 2009; Mohorji et al. 2017). Changes in the

61 long-term trends in mean temperature and shifting rainfall patterns, increasing variability, and greater prevalence of extreme events are the facet of climate change. Shifting rainfall patterns may exert a more substantial effect on rice production. However, frequent floods due to heavy rainfall may result in higher rice yield losses under climate change (Wassmann et al. 2009). Climate change results from increasing human activities on the land, including deforestation, land use, urbanisation, increasing population, production and consumption activities to fulfil people's

67 demand for food supply. Climate steadily changes due to global temperature, precipitation, and carbon emission, significantly impacting agricultural productivity and growth (Chandio et al. 2021; Klutse et al. 2021).

Agricultural productivity has decreased due to climate change's main drivers, such as precipitation and warmer temperature (Haile et al.2017). However, increase in temperature, variation in rainfall, and frequent floods and droughts are mostly faced by the developing nation, situated in the tropical region and relies heavily on the agriculture sector (Janjua et al. 2014). Agriculture and its allied activities are sensitive to climate change, and another hand, it is also contributed to carbon emission (Swaminathan and Kesavan 2012). Climate change is harmful to agriculture production and enhances the vulnerability among small and medium farmers whose livelihoods are mainly dependent on agricultural and allied activities (Zakaria et al. 2020). climate change‘s impact may vary from region to region based on geographical location. In the case of a developing nation, climate change deteriorates the performance of the agriculture sector (Abbas 2020; Janjua et al.2014; Nath and Behera 2011). Likewise, Abbas et al. (2021) revealed that climate change has significantly affected crop production and food security in South Asia in the long. Swaminathan and Kesavan (2012) stated that climate change adversely affected food production. The developing nations are more vulnerable than developed countries due to more extensive dependence on the agriculture sector for livelihood, lack of technological advancement and lack of adaptation policies of climate change on agriculture production (Dogan and Inglesi 2020; Praveen and Sharma 2020; Warsame et al. 2021). However, Chandio et al. (2021) stated that temperature and financial development negatively and positively impact cereal production in Pakistan. While Ahsan et al. 
(2020) demonstrated that energy consumption, labour force, cultivated area, and $\mathrm{CO}_{2}$ are the main

89 determinants of agriculture productivity. Likewise, Warsame (2021) explained mean temperature and $\mathrm{CO}_{2}$ has negatively influenced agriculture productivity in Somalia. Similarly, Coulibaly et al.

91 (2020) concluded that temperature and drought are the main factors that negatively affect 92 agriculture productivity. Increasing carbon emission leads to a cascade of impact mechanisms that have harmful and beneficial effects on rice production.

In World, Asian countries produce rice about $90 \%$ of the world's total rice production (FAO, 2019) . However, India is the first largest exportable country of rice in the world counted 9.8 million tonnes, followed by Thailand (7.5 million tonnes), Vietnam (6.5 million tonnes), Pakistan (4.6 million tonnes) and the USA (3.1 million tonnes). India is the second rice producer in Asia after China, followed by Indonesia, Bangladesh and Vietnam (Figure 1). The Indian agriculture sector is the most sensitive and exposed area to climate change due to its less adaptive capacity to cope with it (Guntukula 2019). Investigating the impact of climate change on agriculture productivity is of immense importance because more than $50 \%$ population of India primarily depends on agricultural activities for their livelihoods (Pattanayak and Kumar 2013). Changes in environmental factors such as temperature, precipitation, $\mathrm{CO}_{2}$, and rainfall pattern directly affect agriculture productivity (Res et al. 1998). Increasing carbon emission and global warming created challenges for the countries to cope with it through different strategies and policies (Alharthi et al. 2021). Therefore, it is indispensable to examine the effect of changes in climatic conditions on rice production. More than $60 \%$ of the population in India mainly depends on agriculture and its allied sectors (Baig et al. 2020). Trends of rice production and area under crop are shown in Figure 2. Rice output grew from 746.8 (Lakh Tonne) in 1991 to 1164.8 (Lakh tonnes) in 2018. Simultaneously, the cultivated rice area in India has increased from 427 (Lakh Hectare) in 1991 to 442 (Lakh Hectare) in 2018. The area under rice has risen by around 1.5 times, but rice production has increased by more than five times. 


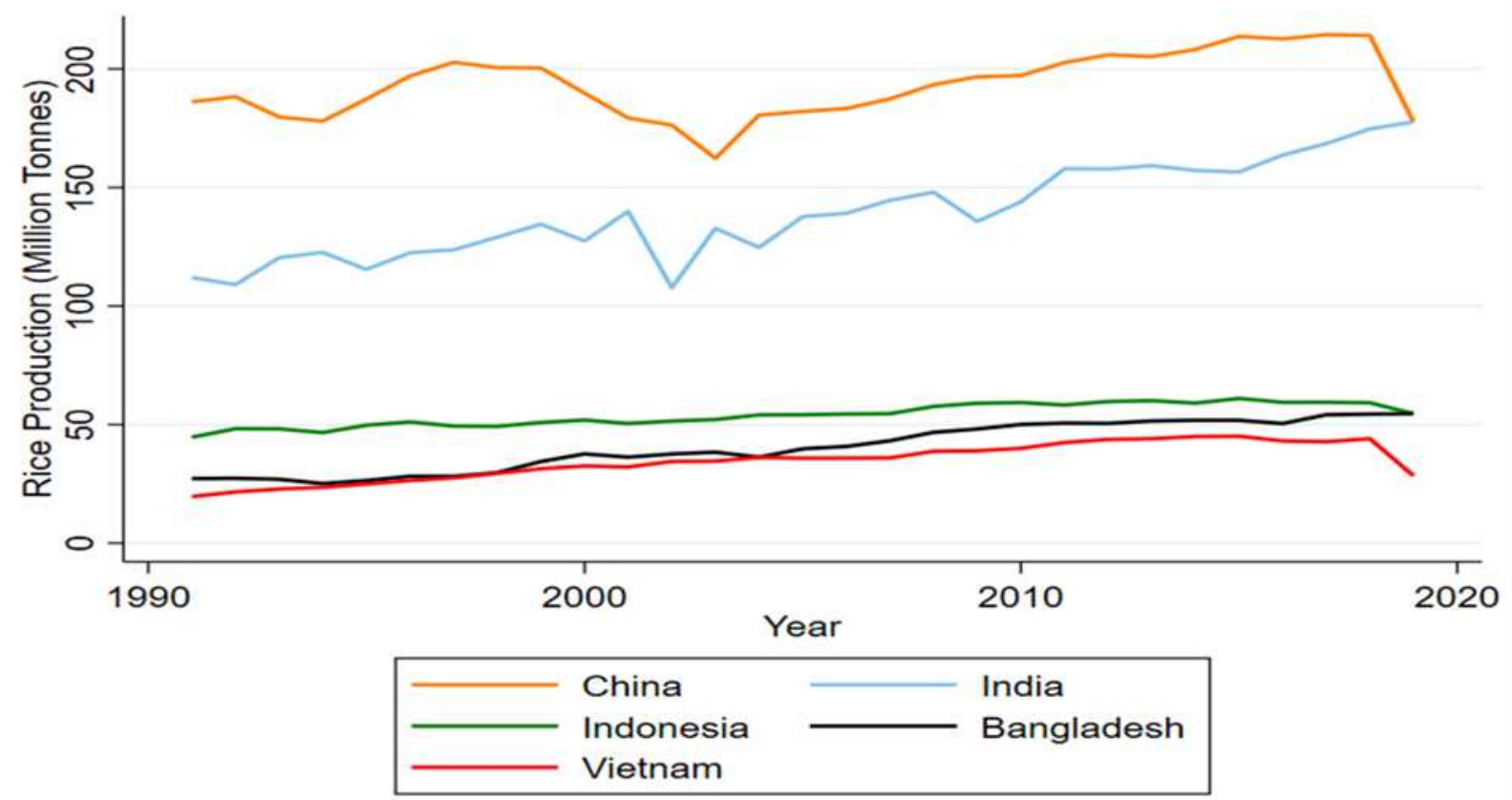

113

114

Figure 1. Top Five Asian Rice Producing Countries

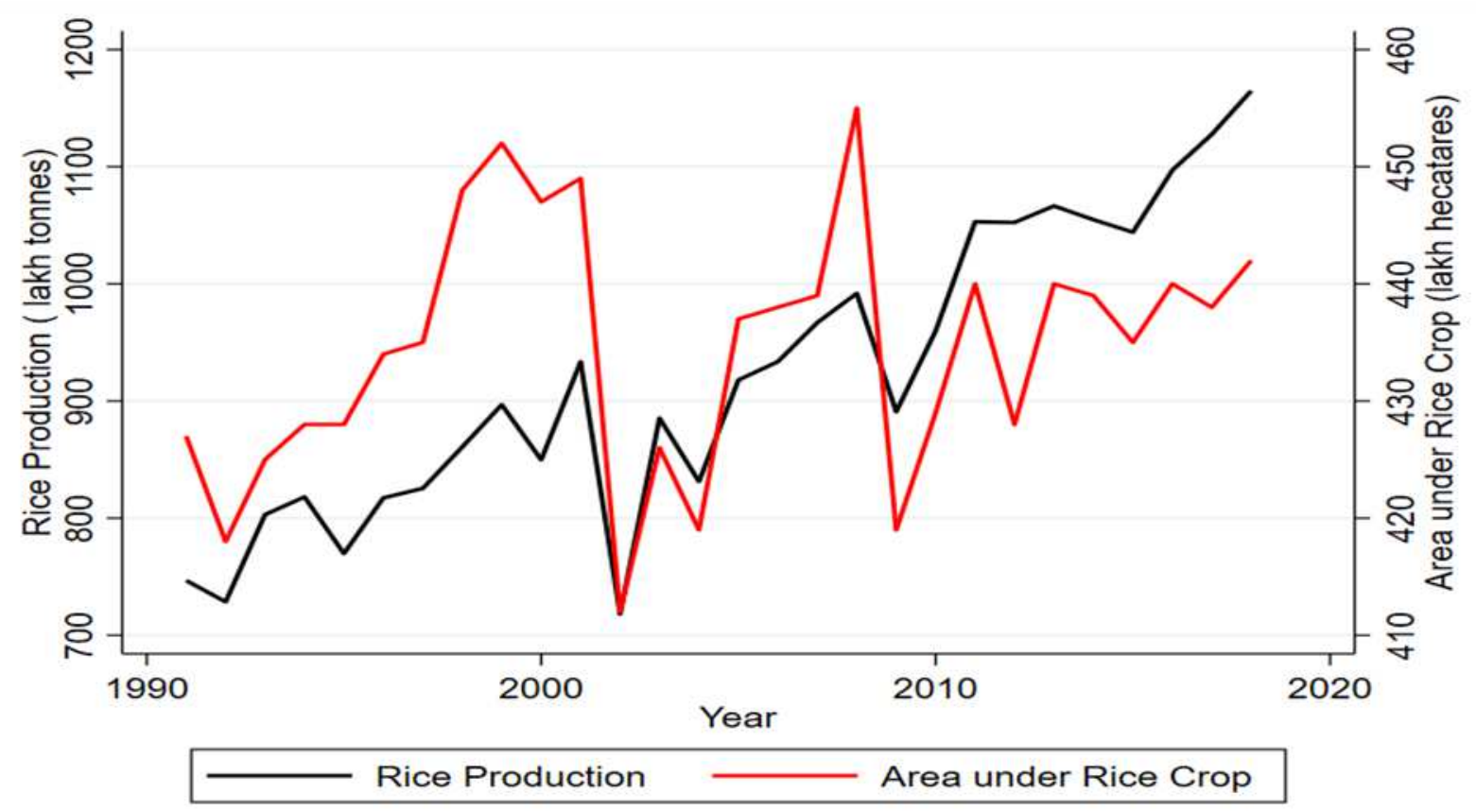

115

117 Climate change may be the effect of food security by hampering agriculture productivity from one-

118 way and multiple ways. Climate change, on the other hand, has a global impact, and its negative

119 consequences are projected to be more severe in India's agro-ecological zones. Climate models

120 predict the severe impacts of climate change on the agriculture sector (Bahl 2015). Climate change 
121 has significantly affected agricultural productivity and food supply, threatening food security 122 (Moses et al. 2015). Because rice is more vulnerable to fluctuation due to climate change and its associated components, the rising negative effects of climatic change would put pressure on

124 agricultural yield (Bahl 2015). Given rice's vulnerability to environmental change, particularly 125 those connected to temperature increases and extended drought spells, meeting future global rice demand appears to be a difficult undertaking. Temperature-related changes in the duration of the

127 growing season will reduce rice yield and shift farming frameworks away from rice and toward 128 crops with greater temperature optimums (Korres et al. 2017).

130 This study explores the nonlinear effects of climate change on rice production in India, spanning 131 from 1991 to 2018. Most studies employed crop simulation model (Gupta and Mishra 2019; Kumar 132 2011; Kumar et al. 2011; Lal et al. 1998; Mishra and Chandra 2016; Mukherjee and Huda 2018), 133 linear econometric models (Baig et al. 2020; Bhanumurthy and Kumar 2018; Birthal et al. 2014; 134 Guntukula 2020; Kumar et al. 2020; Nath and Mandal 2018; Praveen and Sharma 2020; Gupta et 135 al. 2012) and nonlinear model (Mitra 2014; Pal and Mitra 2018) to assess the impact of climate 136 change on India's agriculture production. Several studies examine the effect of climate change on 137 rice yield or production using linear regression analysis. As a result, these studies have produced 138 only linear effects that might lack nonlinear effects. This study adds to the previous literature by 139 addressing the asymmetric impact of climate change on rice production in India rather than 140 sticking to a linear approach.

141 In this study, we also incorporated other important variables such as rural population, agricultural 142 credit, consumption of fertiliser and cultivated land in the model to examine the impact of these 143 factors on rice production. It is essential to investigate the asymmetrical implications, as it helps 144 to understand whether positive and negative shocks dominate rice production in India. In this 145 manner, this work adopts a more comprehensive understanding. Also, it provides the main factors 146 of rice production for India, which will help formulate economic policies to cope with climate 147 change and enhance rice production in India and other countries with the same agriculture profile.

148 The remainder of the paper is framed as follows: Section 2 deals with the existing literature. The 149 data and technique are discussed in Section 3.Section 4 presents the empirical findings and 150 comments, while Section 5 concludes with policy implications. 


\section{Literature Review}

153 Numerous studies have been done on the nexus between climate change and agricultural 154 productivityand growth across the globe. There is growing consensus among environmentalists 155 and researchers that a negative relationship exists between climate change and agriculture 156 productivity in developing nations (Khanal et al. 2018). South Asia is the most susceptible terrain 157 to climate change globally, with the largest population growth, poverty, and insecurity. Climate 158 change such as extreme weather, unexpected rainfall and temperature fluctuations severally affect agriculture production in developing nations (Masud et. Al. 2014; Shabbir et al. 2020). However,

160 it is the primary concern to frame a suitable policy to tackle climate change problems for 161 policymakers, researchers, and government organisations. At the global, regional level, researchers 162 have undertaken numerous studies to assess the impact of climate change on the agriculture sector 163 (Chandio et al. 2020; Praveen and Sharma 2020; Warsame et al.2021).

164 Among previous studies conducted by Gupta and Mishra (2019) at the India level and Kumar et 165 al. (2020) at the states level, i.e., Uttar Pradesh and Haryana respectively employ the Crop 166 Simulation Model (CSM) and Ricardian regression approach to assess the nature of the 167 relationship between climate change and rice productivity. According to Gupta and Mishra (2019), 168 the multi-Global Climate Model predicts an increase in rice productivity in most agro-ecological zones in Representative Concentration Pathways (RCP) 2.6.Guiteras (2009) explained that major crop yield would harmfully be affected by 4.5 to $9 \%$ due to climate variation from 2010 to 2039 in India. In the same order, the crop would reduce up to $25 \%$ in the absence of adaptation

172 productivity. Kumar et al. (2020) found that any large deviation in the rainfall harms rice and 173 wheat production in Uttar Pradesh.

174 On the other hand, maximum temperature has a negative impact on rice and wheat in Uttar Pradesh 175 and Haryana. While rising temperatures have a positive effect on rice production, they have a 176 detrimental effect on grain. Abbas and Mayo (2019) reported that maximum temperature harms 177 rice plants. Rice crops at the replantation stage during the vegetative phase have benefited from a 178 decrease in the number of plants in the plantation stage and a lower minimum temperature. During 179 the heading and flowering periods, rain has a deleterious impact on rice crops. Likewise, 180 Auffhammer et al. (2012) point out that heavy rainfall and drought have a negative effect on rice 181 yield in the rain-fed areas during the 1966-2002 period, and lower rainfall and warmer night would 
182 not occur then rice yield would increase by 4 per cent in India. In contrast, Rayamajhee et al. 183 (2020) stated that there is no direct relationship between rainfall and rice production in Nepal. 184 Likewise, Abbas et al. (2021) conducted their study and employed the ARDL cointegration 185 approach to investigate climate factors (CO2, Average temperature and precipitation), 186 technological advancement (consumption of fertiliser used as a proxy variable), and other 187 controlled variables such as the area under cultivated land, improves seed, and agriculture credit 188 on rice production. They stated that average temperature and precipitation positively influenced 189 rice production, while $\mathrm{CO}_{2}$ has a significant and negative impact on rice production in Nepal. 190 Furthermore, agriculture credit and area under cultivated land has a positive effect on rice 191 production.

192 Pickson et al. (2021) explored the relationship between climate change and rice production using 193 panel data spanning 1998-2017 in Provinces of China. The long-runand short-run effects of climate 194 change on rice production were investigated using pooled mean group methodologies. Rice 195 production has been positively influenced by average rainfall, while rice production has been 196 negatively influenced by average temperature, according to the study. In the long run, rice 197 production has been positively influenced by cultivated area and fertiliser consumption, according 198 to the findings. Furthermore, the causality test revealed that cultivated land and rice production 199 have bidirectional connection.

200 Similarly, Inayatullah et al. (2021) have investigated the impact of climate change on cereal crops, 201 namely wheat and maise, in the Khyber Pakhtunkhwa (KP) province of Pakistan using panel data 202 from 1986 to 2015 . The result indicated that precipitation has a significant and positive impact on 203 wheat and maise yield in the long and short run. In the short run, minimum temperature has a large 204 beneficial effect on maize yield but has no effect on wheat output, according to the estimated 205 results. Maximum temperature, on the other hand, has had a detrimental impact on wheat and 206 maise yields while having a beneficial impact on crop output in the short term.

207 Attiaoui and Boufateh (2019) and Abbas (2020) find a linear long-run dynamic relationship 208 between climate change and agriculture productivity. Empirical results reveal that deficiency of 209 rainfall and high temperature respectively has negatively and positively affected agriculture 210 productivity. Baig et al. (2020) also employ a linear dynamic ARDL model to assess the impact 211 of climate change on the yield of major crops, including rice, wheat, coarse cereals and pulse in 212 India. Findings showed that temperature positively impacts wheat, coarse grains and pulse except 
213 for rice. At the same time, rainfall has a positive impact on rice, coarse cereals and pulse except

214 for wheat in India. In contrast, Mitra (2014) and Pal and Mitra (2018) investigated the nonlinear

215 relationship between climate change and crop productivity in India. Mitra (2014) found no

216 asymmetric relationship between rainfall and food grain in India and observed that average rainfall

217 has a greater impact on food grain production than below-average rain. In contrast, Pal and Mitra

218 (2018) explain that rainfall has a greater effect on food grain production up to 75 th quantile and

219 reduces after that in India. While Nsabimana and Habimana (2017) conducted a study in Rwanda's

220 context, they stated that rainfall has an asymmetric impact on crop prices in the short and long run.

221 Furthermore, the price of food crops has decreased during the harvest season and then increased.

222 Likewise, Moore et al. (2017) used database yield to compare results from process-based and

223 empirical studies in order to comprehensively investigate the influence of climate change on

224 agricultural production and welfare. He claims that the asymmetric impacts of climate change on

225 welfare and agricultural yield show a high possibility of severe welfare losses with warming of 2-

2263 degrees Celsius, even after accounting for the $\mathrm{CO}_{2}$ fertilisation effect. Fezzi and Bateman (2016)

227 and Kabubo-mariara and Karanja (2007) has observed a nonlinear relationship between climate

228 change and the revenue of agriculture crops. So, it is challenging to cope with it due to the complex

229 asymmetrical association between climate change and agriculture production. Table 1 shows a

230 summary of review of literature.

231

232 Table 1. Summary of Review of Literature

\begin{tabular}{|c|c|c|c|c|c|}
\hline $\begin{array}{l}\text { S. } \\
\text { No. }\end{array}$ & Author(s) & Time & Country(ies)/State(s) & Model(s) & Results \\
\hline 1 & $\begin{array}{l}\text { Chandio et } \\
\text { al. (2019) }\end{array}$ & $\begin{array}{l}1968- \\
2014\end{array}$ & Pakistan & ARDL & $\begin{array}{l}\text { +CO2, Avg. Temperature, } \\
\text { Area under cultivation---> } \\
\text { +Rice production both in } \\
\text { short and long run. } \\
\text { +Fertilizers---> +Rice } \\
\text { production in long run but - } \\
\text { Rice production in short } \\
\text { run. }\end{array}$ \\
\hline 2 & $\begin{array}{l}\text { Chandio et } \\
\text { al. (2021) }\end{array}$ & $\begin{array}{l}1980- \\
2016\end{array}$ & Turkey & ARDL & $\begin{array}{l}\text { +CO2--> -Rice Production } \\
\text { both in short \& long run. } \\
\text { +Temperature, } \\
\text { Precipitation, Area } \\
\text { harvested of rice---> +Rice }\end{array}$ \\
\hline
\end{tabular}


production both in short and long run.

+Domestic Credit---> -Rice production in long run but +Rice Production in short run.

\begin{tabular}{|c|c|c|c|c|c|}
\hline 3 & $\begin{array}{l}\text { Yuliawan } \\
\text { et al. } \\
(2016)\end{array}$ & $\begin{array}{l}1970- \\
2004\end{array}$ & Indonesia & $\begin{array}{l}\text { Crop } \\
\text { simulation } \\
\text { model }\end{array}$ & $\begin{array}{l}\text { +Temperature---> -Rice } \\
\text { production. }\end{array}$ \\
\hline 4 & $\begin{array}{l}\text { Krishnan et } \\
\text { al. (2007) }\end{array}$ & $\begin{array}{l}2001- \\
2003\end{array}$ & Eastern India & $\begin{array}{l}\text { ORYZA1 } \\
\& \\
\text { INFOCROP } \\
\text { simulation } \\
\text { model }\end{array}$ & $\begin{array}{l}\text { +CO2---> +Rice yield. } \\
\text { +Temperature---> -Rice } \\
\text { yield. }\end{array}$ \\
\hline 5 & $\begin{array}{l}\text { Lal et al. } \\
(1998)\end{array}$ & $\begin{array}{l}1965- \\
1994\end{array}$ & North-West India & $\begin{array}{l}\text { CERES rice } \\
\text { model }\end{array}$ & $\begin{array}{l}+\mathrm{CO} 2--->+ \text { Rice yield. } \\
\text { Rise in air temperature } \\
\text { cancel out the positive } \\
\text { effect of +CO2. } \\
+ \text { Tmin---> -Rice yield. }\end{array}$ \\
\hline 6 & $\begin{array}{l}\text { Chandio et } \\
\text { al. }(2021)\end{array}$ & $\begin{array}{l}1990- \\
2016\end{array}$ & Nepal & ARDL & $\begin{array}{l}\text { +CO2---> -Rice production } \\
\text { in long run. } \\
+ \text { Avg. Temperature, Avg. } \\
\text { Precipitation, Cultivated } \\
\text { rice area, Fertilizer, } \\
\text { Agriculture Credit---> } \\
\text { +Rice production in long } \\
\text { run. }\end{array}$ \\
\hline 7 & $\begin{array}{l}\text { Warsame et } \\
\text { al. }(2021)\end{array}$ & $\begin{array}{l}1985- \\
2016\end{array}$ & Somalia & $\begin{array}{l}\text { ARDL, } \\
\text { Granger } \\
\text { causality. }\end{array}$ & $\begin{array}{l}\text { +Rainfall---> +Crop } \\
\text { production in long run but - } \\
\text { Crop production in short } \\
\text { run. } \\
\text { +Temperature---> -crop } \\
\text { production both in short } \\
\text { and long run. } \\
\text { +Land under cereal---> } \\
\text { +Crop productivity in long } \\
\text { run. } \\
\text { CO2 do not have any } \\
\text { significant impact on crop } \\
\text { production. }\end{array}$ \\
\hline 8 & $\begin{array}{l}\text { Matthews } \\
\text { et al. } \\
\text { (1997) }\end{array}$ & & Asia & $\begin{array}{l}\text { ORYZA1 } \\
\& \text { SIMRIW } \\
\text { simulation } \\
\text { model }\end{array}$ & $\begin{array}{l}\text { +CO2---> +Rice yield. } \\
\text { +Temperature---> -Rice } \\
\text { yield. }\end{array}$ \\
\hline
\end{tabular}




\begin{tabular}{|c|c|c|c|c|c|}
\hline 9 & $\begin{array}{l}\text { Saseendran } \\
\text { et al. } \\
(2000)\end{array}$ & & Kerala & $\begin{array}{l}\text { CERES- } \\
\text { Rice V3 } \\
\text { Simulation } \\
\text { model }\end{array}$ & $\begin{array}{l}\text { +CO2, Rainfall---> +Rice } \\
\text { Yield. } \\
\text {-Rainfall---> -Rice yield. } \\
\text { +Temperature---> -Rice } \\
\text { yield. }\end{array}$ \\
\hline 11 & $\begin{array}{l}\text { Muhammad } \\
\text { Nasrullah } \\
\text { et al. } \\
\text { (2021) }\end{array}$ & $\begin{array}{l}1973- \\
2018\end{array}$ & South Korea & ARDL & $\begin{array}{l}\text { +CO2, Mean Temperature, } \\
\text { Area under rice---> +Rice } \\
\text { production both in long \& } \\
\text { short run. } \\
\text { +Rainfall---> -Rice } \\
\text { production both in long \& } \\
\text { short run. } \\
\text { +Fertilizer---> +Rice } \\
\text { production in long run but } \\
\text { has no impact in short run. }\end{array}$ \\
\hline 12 & $\begin{array}{l}\text { Chandio et } \\
\text { al. }(2020)\end{array}$ & $\begin{array}{l}1982- \\
2014\end{array}$ & China & ARDL & $\begin{array}{l}\text { +CO2, Fertilizer, Land } \\
\text { under cereal crops---> } \\
+ \text { Agricultural output both } \\
\text { in short \& long run. } \\
\text { +Temperature, Rainfall---> } \\
\text {-Agricultural output both in } \\
\text { short \& long run. }\end{array}$ \\
\hline 13 & $\begin{array}{l}\text { Siddiqui et } \\
\text { al. (2012) }\end{array}$ & $\begin{array}{l}1980- \\
2009\end{array}$ & Punjab, Pakistan & $\begin{array}{l}\text { Fixed } \\
\text { Effect } \\
\text { Model } \\
{[\text { FEM] }}\end{array}$ & $\begin{array}{l}\text { +Temperature---> +Rice } \\
\text { production initially but } \\
\text { harmful beyond a certain } \\
\text { optimal temperature. } \\
\text { +Precipitation does not } \\
\text { harm rice productivity. }\end{array}$ \\
\hline 14 & $\begin{array}{l}\text { Haris et al. } \\
(2010)\end{array}$ & $\begin{array}{l}2006- \\
2008\end{array}$ & Bihar & $\begin{array}{l}\text { INFOCROP } \\
\text { simulation } \\
\text { model }\end{array}$ & $\begin{array}{l}\text { +CO2---> +Rice yield. } \\
\text { +Temperature---> -Rice } \\
\text { yield. }\end{array}$ \\
\hline 15 & $\begin{array}{l}\text { Kingra et } \\
\text { al. (2018) }\end{array}$ & $\begin{array}{l}1974- \\
2013\end{array}$ & Punjab, India & $\begin{array}{l}\text { Stepwise } \\
\text { Regression }\end{array}$ & $\begin{array}{l}\text { +Tmin , Tmax, Rainfall---> } \\
\text {-Rice production. } \\
\text { +Fertilizer, Total cropped } \\
\text { area---> +Rice production. }\end{array}$ \\
\hline 16 & $\begin{array}{l}\text { Sajjad Ali } \\
\text { et al. } \\
(2017)\end{array}$ & $\begin{array}{l}1989- \\
2015\end{array}$ & Pakistan & FGLS & $\begin{array}{l}\text { +Rainfall, Temperature---> } \\
\text {-Rice crop yield. }\end{array}$ \\
\hline 17 & $\begin{array}{l}\text { Sohail } \\
\text { Abbas et al. } \\
(2021)\end{array}$ & $\begin{array}{l}1979- \\
2018\end{array}$ & Punjab, Pakistan & $\begin{array}{l}\text { ARDL \& } \\
\text { NARDL }\end{array}$ & $\begin{array}{l}\text { Varying effect of } \\
\text { temperature and rainfall on } \\
\text { rice crop in different } \\
\text { region. }\end{array}$ \\
\hline
\end{tabular}




\begin{tabular}{|c|c|c|c|c|}
\hline & & & & $\begin{array}{l}\text { Asymmetric relation } \\
\text { between climate and rice } \\
\text { production. }\end{array}$ \\
\hline 18 & $\begin{array}{l}\text { Hussain et } \\
\text { al. (2012) }\end{array}$ & $\begin{array}{l}\text { 1988- Pakistan } \\
2010\end{array}$ & $\begin{array}{l}\text { Log linear } \\
\text { Cobb- } \\
\text { Douglas } \\
\text { production } \\
\text { function }\end{array}$ & $\begin{array}{l}\text { +Fertilizer, Credit } \\
\text { disbursement---> +Rice } \\
\text { production though } \\
\text { statistically insignificant. } \\
\text { +Area under cultivation---> } \\
\text { +Rice production. }\end{array}$ \\
\hline 19 & $\begin{array}{l}\text { Bashir et al. } \\
(2010)\end{array}$ & Lahore, Pakistan & $\begin{array}{l}\text { Cobb- } \\
\text { Douglas } \\
\text { production } \\
\text { function }\end{array}$ & $\begin{array}{l}\text { +Agriculture credit---> } \\
\text { +Rice productivity. }\end{array}$ \\
\hline
\end{tabular}


235 In this study we explores asymmetrical causal relationship between climate change and rice 236 production in India using

237 times series data from 1991-2018. The data is obtained from different sources includings Reserve 238 Bank of India (RBI), World development Indicators (WDI), and the Climate change knowledge 239 portal (CCKP) (Table 2). Figure 3 represenets the trend of the variables.

240 Table 2. Description of the Variables

\begin{tabular}{|l|l|l|l|}
\hline Variables & Abbreviations & Units & Sources \\
\hline Rice Production & $\ln \mathrm{PR}$ & Lakh Tonne (LT) & RBI \\
\hline Mean Temperature & $\ln \mathrm{AT}$ & Celsius (c) & CCKP \\
\hline Average Rainfall & $\ln \mathrm{RF}$ & Milli Meter (mm) & CCKP \\
\hline Carbon Emission & $\operatorname{lnCO} 2$ & Kiloton(kt) & WDI \\
\hline Rural Population & RP & \% of Total Population & WDI \\
\hline Agricultural Credit & $\ln \mathrm{AC}$ & Crore (Cr) & RBI \\
\hline $\begin{array}{l}\text { Consumption } \\
\text { Fertiliser }\end{array}$ & $\operatorname{lnF}$ & $\begin{array}{l}\text { Kilogram/Hectare } \\
(\text { Kg/hc) }\end{array}$ & RBI \\
\hline Area Under Rice crop & $\ln$ AUR & Lakh Hectare (Lh) & RBI \\
\hline
\end{tabular}

241 Note: RBI indicates Reserve Bank of India, CCKP means Climate Change Knowledge Portal and 242 WDI represent World Development Indicators

243

244 This study undertakes rice production (Lakh Tonne) as a dependent variable, mean temperature 245 (C), average rainfall (mm), carbon emission (kt), rural population (Per cent of the total population), 246 consumption of fertiliser (kg/ha), agriculture credit (Crore) and area under crops (Lakh hectare) 247 used as independents variables. Annual mean temperature, annual average rainfall and carbon 248 emission are the main factors of climate change (Chandio et al. 2020; Kumar et al. 2021; Pickson 249 et al. 2021). Chandio et al. (2021), Pickson et al. (2021) and Warsame et al. (2020) also

250 incorporated agriculture credit, consumption of fertiliser, rural population and area under crops as 251 non-climate factors of agriculture production. All the variables were transformed into logarithmic. 252 Figure 6 shows trends of underlying variables used in this study. 

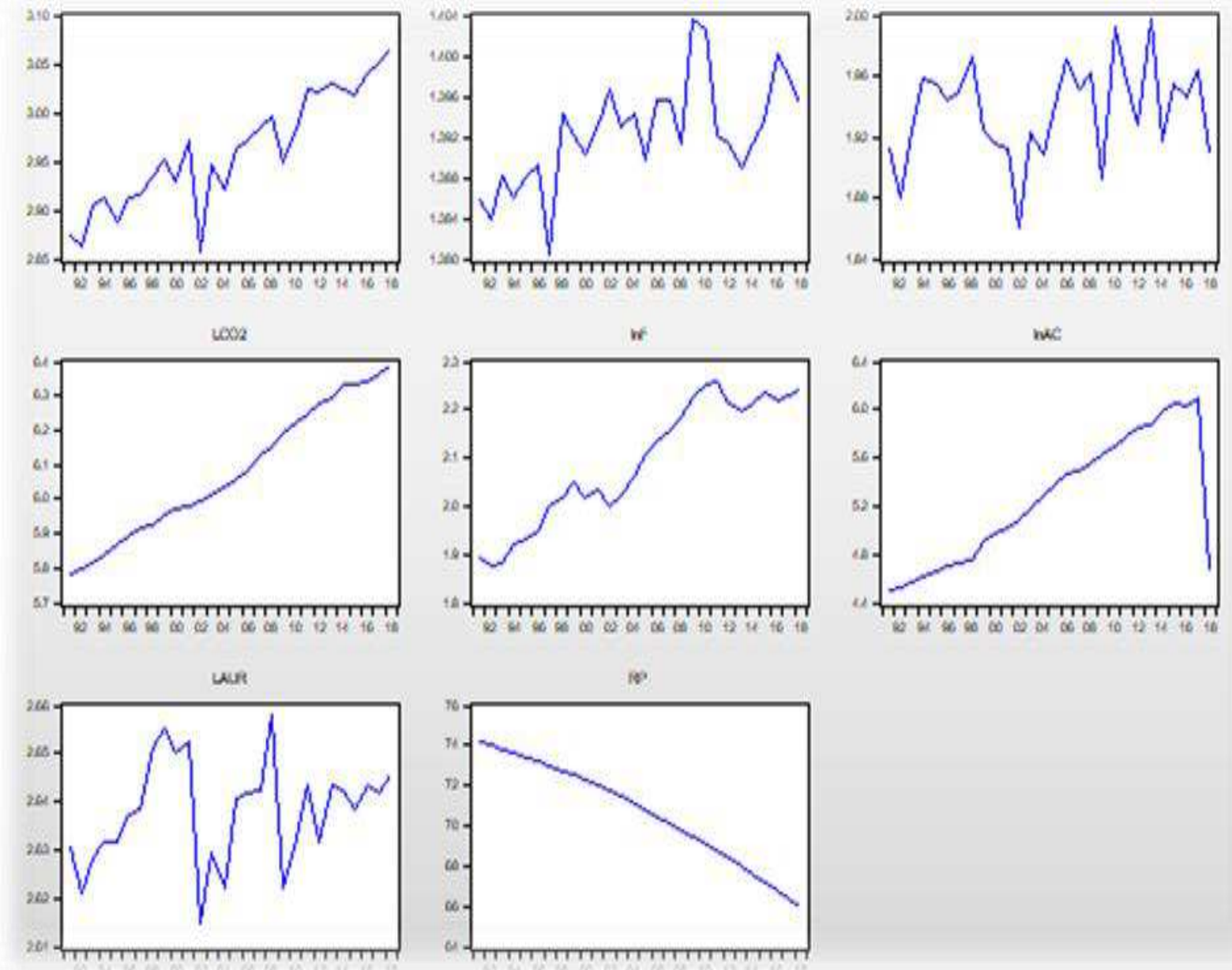

Figure 3. Trends of variables used in this study

\section{NARDL Bound Test for Cointegration}

260 This study employs the recently developed and advanced technique NARDL to investigates the

261 asymmetrical effect of climate change on production of rice. The ARDL technique ignored

262 nonlinearity and the asymmetrical association between the underlying variables. An ARDL model

263 is expanded to an asymmetric ARDL or NARDL by Shin et al. (2014) to assess the pattern of

264 dynamic adjustment and asymmetries relationship in the short and long run between the variables.

265 To explore the relationship between the variables following model can be specified as:

$266 \ln P R_{t}=f\left(\ln A T_{t}, \ln R F_{t}, \ln C O_{2 t}, R P_{t}, \ln A C_{t}, \ln F_{t}, \ln A U R_{t}\right)$

268 We can rewrite equation (1) as follows: 
$\ln P R_{t}=\alpha_{0}+\alpha_{1} \ln A T_{t}+\alpha_{2} \ln R F_{t}+\alpha_{3} \ln C O_{2 t}+\alpha_{4} R P_{t}+\alpha_{5} \ln A C_{t}+\alpha_{6} \ln F_{t}+\alpha_{7} \ln A U R_{t}+$ $\varepsilon_{t}$

Where $\ln P R$ is the natural $\log$ of rice production, $\ln \mathrm{AT}$ is the natural $\log$ mean temperature, $\operatorname{lnRF}$ is the natural $\log$ of average rainfall, $\operatorname{lnCO}_{2}$ is the natural $\log$ carbon emission, $\mathrm{RP}$ is rural population, $\ln \mathrm{AC}$ is the natural $\log$ of agricultural credit, $\ln \mathrm{F}$ is the natural $\log$ of consumption of fertiliser and $\ln$ AUR indicates natural $\log$ of the area under rice crop. Before presenting a full depiction of the NARDL model, General forms of long-run asymmetry relationships are given as follows:

$$
\begin{aligned}
\ln P R_{t}= & \alpha_{0}+\alpha_{1}^{+} \ln A T_{t}^{+}+\alpha_{2}^{-} \ln A T_{t}^{-}+\alpha_{3}^{+} \ln C O_{2 t}^{+}+\alpha_{4}^{-} \ln C O_{2 t}^{-}+\alpha_{5}^{+} \ln R F_{t}^{+}+\alpha_{6}^{-} \ln R F_{t}^{-}+ \\
& \alpha_{7}^{+} R P_{t}^{+}+\alpha_{8}^{-} R P_{t}^{-}+\alpha_{9} \ln A C_{t}+\alpha_{10} \ln F_{t}+\alpha_{11} \ln A U R_{t}+\varepsilon_{t}
\end{aligned}
$$

Where, $\operatorname{lnPR}_{\mathrm{t}}$ is a $\mathrm{k} \times 1$ vector of rice production at time $\mathrm{t}$, where, $\alpha\left(\alpha_{0}, \alpha_{1}^{+}, \alpha_{2}^{-}, \alpha_{3}^{+}, \alpha_{4}^{-}, \alpha_{5}^{+}\right.$, $\alpha_{6}^{-}, \alpha_{7}^{+}, \alpha_{8}^{-}, \alpha_{9}, \alpha_{10}$ and $\left.\alpha_{11}\right)$ are the associated asymmetric long-run parameters. Here $\ln \mathrm{AT}_{\mathrm{t}}$, $\operatorname{lnRF} \mathrm{t}_{\mathrm{t}}, \quad \operatorname{lnCO}_{2 \mathrm{t}}$, and $\mathrm{RP}_{\mathrm{t}}, \quad$ as $\mathrm{k} \times 1$ vector of regressors is subdivided as; $\ln A T_{t}=\ln A T_{0}+\ln A T_{t}^{+}+\ln A T_{t}^{-}, \ln R F_{t}=\ln R F_{0}+\ln R F_{t}^{+}+\ln R F_{t}^{-}, \ln C O_{2 t}=\ln C O_{20}+\ln C O_{2 t}^{+}+\ln C O_{2 t}^{-}$ and $R P_{t}=R P_{0}+R P_{t}^{+}+R P_{t}^{-}$respectively.

Where, $\ln A T_{t}^{+}, \ln A T_{t}^{-} ; \ln R F_{t}^{+}, \ln R F_{t}^{-} ; \ln C O_{2 t}^{+}, \ln C O_{2 t}^{-}$and $R P_{t}^{+}, R P_{t}^{-}$are partial sum processes of positive (+) and negative (-) changes in $\ln A T_{t}, \ln R F_{t}, \ln C O_{2 t}, R P_{t}$ respectively. Equation shows partial decomposition of $\ln \mathrm{AT}, \operatorname{lnRF}, \operatorname{lnCO}_{2}$ and $\mathrm{RP}$.

$$
\ln A T_{t}^{+}=\sum_{i=1}^{t} \Delta \ln A T_{i}^{+}=\sum_{i=1}^{t} \max \left(\Delta \ln A T_{i,}, 0\right)
$$

$$
\ln A T_{t}^{-}=\sum_{i=1}^{t} \Delta \ln A T_{i}^{-}=\sum_{i=1}^{t} \min \left(\Delta \ln A T_{i,}, 0\right)
$$

$$
\ln R F_{t}^{+}=\sum_{i=1}^{t} \Delta \ln R F_{i}^{+}=\sum_{i=1}^{t} \max \left(\Delta \ln R F_{i,}, 0\right)
$$

$$
\ln R F_{t}^{-}=\sum_{i=1}^{t} \Delta \ln R F_{i}^{-}=\sum_{i=1}^{t} \min \left(\Delta \ln R F_{i,}, 0\right)
$$

$$
\ln C O_{2 t}^{+}=\sum_{i=1}^{t} \Delta \ln C O_{2 i}^{+}=\sum_{i=1}^{t} \max \left(\Delta \ln C O_{2 i,}, 0\right)
$$


300

302

303

304

305

306

307

308

309

310

$$
\operatorname{lnC} O_{2 t}^{-}=\sum_{i=1}^{t} \Delta \ln C O_{2 i}^{-}=\sum_{i=1}^{t} \min \left(\Delta \ln C O_{2 i,}, 0\right)
$$

$$
R P_{t}^{+}=\sum_{i=1}^{t} \Delta R P_{i}^{+} \quad=\sum_{i=1}^{t} \max \left(\Delta R P_{i,}, 0\right)
$$

$$
R P_{t}^{-}=\sum_{i=1}^{t} \Delta R P_{i}^{-} \quad=\sum_{i=1}^{t} \min \left(\Delta R P_{i,}, 0\right)
$$

Shin et al., (2014) prolong ARDL model adopted (Peasaran et al. 2001) by utilising the concept of cumulative positive and negative partials sums. In this manner, the NARDL model proposed by Shin et al. (2014), represent asymmetric error correction form is specified as:

$$
\begin{aligned}
\Delta \ln P R_{t}=\alpha_{0} & +\rho \ln P R_{t-1}+\alpha_{1}^{+} \ln A T_{t-1}^{+}+\alpha_{2}^{-} \ln A T_{t-1}^{-}+\alpha_{3}^{+} \ln R F_{t-1}^{+}+\alpha_{4}^{+} \ln R F_{t-1}^{-} \\
& +\alpha_{5}^{+} \ln C O_{2, t-1}^{+}+\alpha_{6}^{+} \ln C O_{2, t-1}^{-}+\alpha_{7}^{+} R P_{t-1}^{+}+\alpha_{8}^{+} R P_{t-1}^{-}+\alpha_{9} \ln F_{t-1} \\
& +\alpha_{10} \ln A C_{t-1}+\alpha_{11} \ln A U R_{t-1}+\sum_{i=1}^{m=p} \beta_{i} \Delta \ln P R_{t-i}+\sum_{m=1}^{m=p}\left(\theta_{1}^{+} \Delta \ln \mathrm{AT}_{t-1}^{+}\right. \\
& \left.+\theta_{2}^{-} \Delta \ln \mathrm{AT}_{t-1}^{-}\right)+\sum_{m=1}^{m=p}\left(\gamma_{1}^{+} \Delta \ln R F_{t-1}^{+}+\gamma_{2}^{-} \Delta \ln R F_{t-1}^{-}\right)+\sum_{m=1}^{p}\left(\vartheta_{1}^{+} \Delta \ln C O_{2 t-1}^{+}\right. \\
& \left.+\vartheta_{2}^{-} \ln C O_{2 t-1}^{-}\right) \\
& +\sum_{m=1}^{m=p}\left(\beta_{1}^{+} \Delta \mathrm{RP}_{t-1}^{+}+\beta_{2}^{-} \mathrm{RP}_{t-1}^{-}\right)+\sum_{m=1}^{p} \delta_{1} \Delta \ln F_{t-1}+\sum_{m=1}^{p} \delta_{2} \Delta \ln A C_{t-1} \\
& +\sum_{m=1}^{p} \delta_{3} \Delta \ln A U R_{t-1}+\varphi E C T_{(-1)} \\
& +U_{t}
\end{aligned}
$$

In the above equation, $\left(\alpha_{i}\right)$, indicates long-run coefficients, while $\left(\theta_{i}\right),\left(\gamma_{i}\right),\left(\vartheta_{i}\right),\left(\beta_{i)}\right.$ and $\left(\delta_{i}\right)$ are the short-run coefficients. The NARDL's estimation method is the same as linear ARDL. The null hypothesis of asymmetrical long-run relationship, $\rho=\alpha^{+}=\alpha^{-}=0$ between the variables. Null hypotheses have been tested by computing the general F-statistics ( $\left(F_{P S S}\right)$ or t-statistics $\left(t_{B D M}\right)$ proposed by Banarjee et al. (1998) determined these values by comparing them to the two critical bounds (lower and upper bound), which define a band including all conceivable classifications of the regressors as solely I (0), I (1), or mutually cointegrated. We accept the null 
324 hypothesis if the F-statistics are less than the lower bound value, i.e. I (0). We can infer that there 325 is no long-run association between the variables. If the F-statistics are in the range I (0) to I (1), 326 the outcome is inconclusive. If the F-value is greater than the I (1) bound value, the null hypothesis 327 can be rejected, indicating that variables are long-run cointegrated. ,ECT-1. is the error correction 328 term, and is the rate at which the asymmetrical long-run equilibrium relationship is restored 329 following a disruption.

330 The long-run $\left(\alpha^{+}=\alpha^{-}\right)$and short-run $\left(\theta_{1}^{+}=\theta_{2}^{-}, \vartheta_{1}^{+}=\vartheta_{2}^{-}, \gamma_{i}^{+}=\gamma_{i}^{-}, \beta_{1}^{+}=\beta_{2}^{-}\right)$asymmetries 331 estimates through the Wald test for mean temperature $(\ln \mathrm{AT})$, average rainfall $(\operatorname{lnRF})$, carbon 332 emission(1CO2) and rural population (RP) variables. Where; $\mathrm{p}$ and $\mathrm{q}$ are representing optimal lags 333 order of dependent and independent variables, respectively. Akaike and Schwarz information 334 criteria have been used to find out the optimal lag selection in the model. The long-term 335 asymmetric coefficients are calculated based on $L_{m i^{+}}=\alpha^{+} / \rho$ and $L_{m i^{-}}=\alpha^{-} / \rho$. These long run 336 coefficients measure the connection between variables in long run equilibrium with respect to 337 independent variable shocks. By utilising the cumulative dynamic multiplier effect, these long-run 338 and short-run asymmetry trajectories can be described in the following ways: a unit percentage 339 change in $X_{t}^{+}$and $X_{t}^{-}$on $Y_{t}$ are obtained through the following equation:

$m_{h}^{+}=\sum_{i=0}^{h} \frac{\partial L P R_{t+i}}{\partial \ln A T_{t}^{+}} ; \quad m_{h}^{-}=\sum_{i=0}^{h} \frac{\partial L P R_{t+i}}{\partial \ln A T_{t}^{-}} ; \quad m_{h}^{+}=\sum_{i=0}^{h} \frac{\partial L P R_{t+i}}{\partial \ln R F_{t}^{+}} ; \quad m_{h}^{-}=\sum_{i=0}^{h} \frac{\partial L P R_{t+i}}{\partial \ln R F_{t}^{-}} ;$

$m_{h}^{+}=\sum_{i=0}^{h} \frac{\partial L P R_{t+i}}{\partial l C O 2_{t}^{+}} ; \quad m_{h}^{-}=\sum_{i=0}^{h} \frac{\partial L P R_{t+i}}{\partial l C O 2_{t}^{-}} ; \quad m_{h}^{+}=\sum_{i=0}^{h} \frac{\partial L P R_{t+i}}{\partial R P_{t}^{+}} ; \quad m_{h}^{-}=\sum_{i=0}^{h} \frac{\partial L P R_{t+i}}{\partial R P_{t}^{-}} ;$

343 Where, if $\mathrm{h} \rightarrow \infty$, then $m_{h}^{+} \rightarrow L_{m i^{+}}$and $m_{h}^{-} \rightarrow L_{m i^{-}}$.

344 The adequacy and stability of the specified NARDL models are also checked with various 345 diagnostic tests.

\section{Results and Discussion}

Table 3 reported result of descriptive statistics. We can infer from table 3 the average value of $\ln \mathrm{PR}, \ln \mathrm{AT}, \operatorname{lnRF} . \operatorname{lnCO} \mathrm{CO}_{2}, \mathrm{RP}, \ln \mathrm{AC}, \operatorname{lnF}$ and $\ln \mathrm{AUR}$ are 2.96, 1.39, 1.94, 6.08, 70.64, 5.25, 2.09 and 2.64 and the standard deviation are $0.06,0.01,0.03,0.19,2.54,0.54,0.13$ and 0.01 respectively. The Jarque Bera test P-value suggests that all variables are normal. 
Table 3: Descriptive Statistics

\begin{tabular}{lllllllll}
\hline Variables & Obs & Mean & $\begin{array}{c}\text { Std. } \\
\text { Dev. }\end{array}$ & Min & Max & Skew. & Kurt. & J-B (P) \\
\hline $\ln \mathrm{PR}$ & 28 & 2.96 & .06 & 2.86 & 3.07 & -.01 & 2 & 0.55 \\
$\ln \mathrm{AT}$ & 28 & 1.39 & .01 & 1.38 & 1.4 & .08 & 3.08 & 0.98 \\
$\ln \mathrm{RF}$ & 28 & 1.94 & .03 & 1.86 & 2 & -.26 & 2.81 & 0.83 \\
$\ln \mathrm{CO} 2$ & 28 & 6.08 & .19 & 5.78 & 6.39 & .12 & 1.69 & 0.35 \\
$\mathrm{RP}$ & 28 & 70.64 & 2.54 & 65.97 & 74.22 & -.29 & 1.83 & 0.37 \\
$\ln \mathrm{AC}$ & 28 & 5.25 & .54 & 4.49 & 6.11 & .12 & 1.59 & 0.30 \\
$\ln \mathrm{n}$ & 28 & 2.09 & .13 & 1.87 & 2.26 & -.21 & 1.64 & 0.30 \\
$\ln \mathrm{AUR}$ & 28 & 2.64 & .01 & 2.61 & 2.66 & -.17 & 2.44 & 0.77 \\
\hline
\end{tabular}

Sources: Calculated by the authors

354 Result of Correlation analysis are reported in Table 4, which indicates that all the variables are

355 positively correlated with production of rice except rural population which are negatively 356 correlated.

$357 \quad$ Table 4: Matrix of correlations

\begin{tabular}{lllllllll}
\hline Variables & $\ln \mathrm{PR}$ & $\ln \mathrm{AT}$ & $\operatorname{lnRF}$ & $\ln \mathrm{CO} 2$ & $\mathrm{RP}$ & $\ln \mathrm{AC}$ & $\ln \mathrm{F}$ & $\ln \mathrm{AUR}$ \\
\hline $\ln \mathrm{PR}$ & 1.00 & & & & & & & \\
$\ln \mathrm{AT}$ & 0.45 & 1.00 & & & & & & \\
$\operatorname{lnRF}$ & 0.43 & 0.04 & 1.00 & & & & & \\
$\operatorname{lnCO} 2$ & 0.92 & 0.60 & 0.27 & 1.00 & & & & \\
$\mathrm{RP}$ & -0.92 & -0.59 & -0.25 & -0.99 & 1.00 & & & \\
$\ln \mathrm{AC}$ & 0.74 & 0.56 & 0.35 & 0.85 & -0.83 & 1.00 & & \\
$\operatorname{lnF}$ & 0.89 & 0.65 & 0.34 & 0.96 & -0.94 & 0.86 & 1.00 & \\
$\ln \mathrm{nUR}$ & 0.53 & 0.01 & 0.47 & 0.26 & -0.24 & 0.16 & 0.32 & 1.00 \\
\hline
\end{tabular}

Sources: Calculated by the Authors

359 The next step is to check the stationarity of the underlying variables to guarantee that none of them

360 are integrated at order 2. Because the NARDL model requires that variables be integrated at order 3610 or 1 to investigate cointegration among variables, a unit root test must be performed. We used 362 the augmented Dickey-Fuller (ADF) and Phillips-Perron (PP) unit root tests in this order, and the 363 results are shown in Table 5. We can infer from Table 5 that mean temperature, average rainfall, 364 rural population, and land area under rice crop are I (0), while rice production, carbon emission 365 and agriculture credit series are I (1). 
366 Table 5: Unit Root analysis without structural break.

\begin{tabular}{lccccc}
\hline Variables & \multicolumn{2}{c}{$\mathbf{I}(\mathbf{0})$} & & \multicolumn{2}{c}{$\mathbf{I}(\mathbf{1})$} \\
\cline { 2 - 3 } \cline { 5 - 6 } & $\mathbf{P P}$ & $\mathbf{A D F}$ & & $\mathbf{P P}$ & $\mathbf{A D F}$ \\
\hline $\ln \mathrm{PR}$ & -2.92 & -1.51 & & $-40.79^{* * *}$ & $-10.27^{* * *}$ \\
$\ln \mathrm{AT}$ & $-13.18^{* *}$ & -2.52 & & $-34.06^{* * *}$ & $-7.14^{* * * *}$ \\
$\ln \mathrm{RF}$ & $-23.57^{* * *}$ & $-.310^{* *}$ & & $-39.88^{* * *}$ & $-9.20^{* * *}$ \\
$\ln \mathrm{CO} 2$ & 0.08 & 0.063 & & $-23.71^{* * *}$ & $-4.589^{* * *}$ \\
$\mathrm{RP}$ & 0.81 & $2.30^{* * *}$ & & -0.22 & $-2.69^{* * *}$ \\
$\ln \mathrm{AC}$ & -4.43 & -1.47 & & $-118.46^{* * *}$ & -1.34 \\
$\ln \mathrm{F}$ & -1.12 & -1.51 & & $-20.98^{* * *}$ & $-4.17^{* * *}$ \\
$\ln \mathrm{n}$ & $-17.09^{* * *}$ & $-3.11^{* *}$ & & $-33.76^{* * *}$ & $-7.95^{* * *}$ \\
\hline
\end{tabular}

367 Sources: Estimated by authors

368 By neglecting structural breakdowns in the data, common unit root tests such as ADF and PP allow 369 results to be misled. To address this issue, we employ the Zivot and Andrews (1991) test. The 370 results of the Zivot and Andrews (1992) test are shown in Table 6, which reveals that rice output, 371 mean temperature, average rainfall, fertiliser usage, and area under rice crop are integrated at order 372 0. In contrast, carbon emission, agricultural credit, and rural population are stationary after being 373 first differenced with different structural breaks in the series. Due to the drought in 2002 in India, 374 agricultural productivity had been sharply gone down (Gulati et al. 2013). Hence the structural 375 break has arisen in the data of rice production. Due to the presence of structural breaks in the data, 376 the variables may have nonlinearity. As a result, to check for nonlinearity, we use the BDS 377 independence test, which checks for the presence of linear dependency in the dependent variable 378 in the model.

Table 6: Result of Structural Breaks Unit Root Test (Zivot \& Andrews, 2002)

\begin{tabular}{cccccc}
\hline Variable & \multicolumn{3}{c}{$\mathrm{I}(0)$} & & \multicolumn{2}{c}{$\mathrm{I}(1)$} \\
\cline { 2 - 3 } \cline { 5 - 6 } $\ln \mathrm{NR}$ & -2.41 & 2010 & & -13.06 & 2002 \\
$\ln \mathrm{AT}$ & -4.69 & 1997 & & -7.3 & 1997 \\
$\ln \mathrm{RF}$ & -5.43 & 2002 & & -9.49 & 1996 \\
$\operatorname{lnCO} 2$ & -2.3 & 2006 & & -4.48 & 1995 \\
$\mathrm{RP}$ & 1.19 & 2003 & & -7.27 & 2001 \\
$\ln \mathrm{AC}$ & -2.79 & 2008 & & -5.3 & 2018 \\
$\operatorname{lnF}$ & -3.28 & 2011 & & -4.97 & 2012 \\
$\ln \mathrm{AUR}$ & -5.24 & 2001 & & -8.04 & 2009 \\
\hline
\end{tabular}

Estimated by Author 
BDS test for nonlinearity in the residual of the dynamic relationship is performed. The result of the BDS are reported in Table 7 indicates that all the variables are not identically and independently distributed (iid) except mean temperature and average rainfall. BDS statistics show the null hypothesis of residual of being independent and identically residual also is rejected at 1 per cent

383 level of significance of rice production at all the dimension. After confirming the nonlinearity in the series, we move towards the estimation of the NARDL model.

Table 7: BDS Test for non-linearity

\begin{tabular}{cccccc}
\hline Variables/BDS Statistics & $\mathrm{D}=2$ & $\mathrm{D}=3$ & $\mathrm{D}=4$ & $\mathrm{D}=5$ & $\mathrm{D}=6$ \\
\hline $\ln \mathrm{PR}$ & $0.08 * * *$ & $0.14 * * *$ & $0.17 * * *$ & $0.19 * * *$ & $0.19 * * *$ \\
$\ln \mathrm{AT}$ & $0.034 * *$ & 0.03 & 0.009 & 0.018 & 0.025 \\
$\ln \mathrm{RF}$ & -0.03 & -0.02 & -0.01 & 0.00 & -0.02 \\
$\operatorname{lnCO} 2$ & $0.18^{* * *}$ & $0.30 * * *$ & $0.38 * * *$ & $0.42 * * *$ & $0.43 * * *$ \\
$\mathrm{RP}$ & $0.18^{* * *}$ & $0.29 * * *$ & $0.37 * * *$ & $0.41 * * *$ & $0.42 * * *$ \\
$\ln \mathrm{AC}$ & $0.16^{* * *}$ & $0.29 * * *$ & $0.38^{* * *}$ & $0.43 * * *$ & $0.47 * * *$ \\
$\ln \mathrm{F}$ & $0.16^{* * *}$ & $0.26 * * *$ & $0.34 * * *$ & $0.39 * * *$ & $0.42 * * *$ \\
$\ln \mathrm{AUR}$ & 0.03 & $0.08^{* * * *}$ & $0.11 * * *$ & $0.11 * * *$ & $0.10 * *$ \\
\hline
\end{tabular}

Estimated by Author

385

386

387

388

389

390

391

392

393

394

395

396

397

398

399

400

401

\section{NARDL Cointegration Results}

Schwrz (1978) information criterion used to choose the optiml lag length of NARDL $(\mathrm{p}, \mathrm{q})$. Then we use general to specific approach by ignoring all insignificant regressors since their inclusion may produce imprecise estimation results. Table 8 deleneat the asymmetric impact of climate change and other controlled agriculture inputs on rice production. Two operational testings are used for the existence of an asymmetrical cointegration relationship based on NARDL. We find that the F-statistics are greater than the critical upper bound value at the $1 \%$ level of significance, confirming the presence of cointegration between mean temperature, average rainfall, carbon emission, rural population, agricultural credit, fertiliser consumption, the area under rice crop, and rice production from 1991 to 2018. The Wald test highlights the importance of asymmetry in both the short and long run, implying that nonlinearity must be considered when researching the relationship between climate change and rice output. At a $1 \%$ level of significance, the t-statistics support the cointegration among the variables. Shin et al. (2014)'s NARDL F-statistics (FPSS) confirm asymmetric cointegration among variables. It means that in India, mean temperature, average rainfall, carbon emissions, agricultural finance, fertiliser usage, rice crop area, and rice production have a long-term asymmetric relationship. 
403 Long and Short-Run Asymmetric Estimates

404 A positive and negative component in mean temperature has a negative and significant impact on 405 rice production, which represent that any positive and negative shock in mean temperature 406 deteriorates rice production. However, the sign of both coefficients is the same but different in 407 magnitude, which indicates mean temperature has a significant asymmetric impact on rice 408 production. This study is in line with previous studies (Chandio et al. 2020; Haris et al. 2013; lal 409 et al. 1998; Matthews et al. 1997; Warsame et al. 2021; Yuliawan and Handoko 2016), corroborates the same findings. Chandio et al. (2020), Matthews et al. (1997), and Warsame et al.

411 (2021) explained temperature has an adverse effect on rice production both in the short and long 412 run. For instance, increases (decreases) 1 per cent in temperature reduces rice production by 9.23 413 (10.32) per cent in the long run in India. Several reasons can support this finding; increasing mean 414 temperature is beneficial for rice production initially. However, beyond a certain optimal 415 temperature, further temperature increases become harmful for rice production. Second, 416 temperature rise would make the age of rice shorter and decrease the rice yield (Kumar et al. 2021). 417 Higher temperature increases sea level; consequently, highly productive rice cultivation areas will 418 be more exposed to inundation and salinity intrusion. Moreover, the increased mean temperature 419 has adversely impacted rice production in various parts of South Asia such as India, Bangladesh, 420 Sri Lanka and Pakistan, which results in reduced average yields by 4 per cent (Matthews et al. 421 1997).

422 Table 8 reported the result of the long run and short asymmetrical impact on rice production. 423 Estimated outcomes in the long-run indicate that positive shock in the rainfall has negative and 424 significant effect on rice production at a 1 per cent level in India. The estimated coefficients of 425 positive shock in average rainfall indicate that a 1 per cent rise in average rainfall leads to a 426 decrease of 1.24 per cent of rice production in India. These findings are supported by the previous 427 study (Abbas et al. 2021; Nasrullah et al. 2021), which stated that excess rainfall has negatively 428 influenced rice production in rain-fed areas. Rice production has tremendous pressure due to the 429 high variability of rainfall in rain-fed regions of India (Pal and Mitra 2018). However, heavy 430 rainfall, i.e., the flood-like situation, has adversely affected rice production in India (Pal and Mitra 431 2018). Some previous studies (Abbas et al. 2021; Chandio et al. 2021; Siddiq et al. 2012; Warsame 432 et al. 2021) has contradicted this result and stated that excess rainfall had enhanced rice production 
433 in rain-fed areas. In contrast, coefficients of negative shocks in the rainfall have a positive and 434 significant impact on rice production at a 1 per cent level in the long run. This study is in line with 435 (Abbas et al. 2021; Mitra 2014), they found that any negative shock in the rainfall has positively 436 affected rice production in India. Pal and Mitra (2018) stated that scanty rainfall and drought have 437 reduced food grain production in India. We can infer from the estimated result that 1 per cent 438 increases (decreases) in average rainfall has reduced (boosts) rice production by approximately $439 \quad 1.24(2.87)$ per cent in India.

440 Any positive shock in the carbon emission has negative impact on rice production at the 1 per cent 441 significance level in India. The estimated outcome indicates a rise in carbon emission in the 442 atmosphere by 1 per cent, which reduces rice production by 1.95 per cent approximately. This 443 outcome is in line with Chandio et al. (2021), who found that carbon emissions have negatively 444 affected rice production in Turkey's short and long run. In contrast, carbon emission negative 445 shocks have an insignificant positive impact on rice production. The coefficient of the negative 446 component of carbon emission indicates that it increases rice production by 0.4 per cent when 1 447 per cent reduce the carbon emission. We can infer from the estimated results that rice production 448 has been boosted by the reduction of carbon emission in the atmosphere in India. Global warming 449 results from increasing carbon emissions in the atmosphere, which is critical in reducing crop 450 production in developing countries (Jan et al. 2021). The positive components have a dominant 451 effect over negative shock on rice production, which implies that increasing carbon emission has 452 harmful for rice production in India.

453 Furthermore, positive shock in the rural population has a statistically insignificant impact on rice production with a coefficient of 0.49 in the long run. Interpretively, rice production is growing by 0.49 per cent due to a 1 per cent increase in rural population. The coefficients indicate that rice 456 production increases with increase in rural population. Whereas, Negative shock in the rural 457 population has negatively influenced rice production by 0.39 per cent in the long run at a 1 per 458 cent level of significance. This study is in line with previous studies (Kumar et al. 2021; Warsame 459 et al. 2021), who found that the rural population has a negative impact on cereals production. It is 460 because the marginal productivity of agriculture labour is zero due to working surplus labour in 461 the same piece of land (Thirlwall 1994). Agriculture labour productivity has decreased because 462 land can not produce more than its capacity (Kumar et al. 2021). 
Table 8 reported the result of the short-run asymmetrical impact on rice output. The positive and negative shocks in mean temperature have positively influenced rice production in India. Estimated coefficients indicate that a 1 per cent increase and decrease in mean temperature can lead to increases the rice production by 17.23 per cent and 2.60 per cent, respectively, which implies that positive shocks have a more dominant effect than the negative shock on rice production in the short run. Results advocated that rice production has more affected by the increasing temperature rather than decreasing temperature in India. Moreover, rainfall positive shock has a negative and significant effect on rice production at a 1 per cent level of significance. It is found that rice production reduced by 0.74 per cent when 1 per cent increase in positive shock of rainfall. In contrast, coefficients of negative shocks in the rainfall have a positive and significant impact on rice production at a 1 per cent level of significance in the short run. We can infer from the estimated result that 1 per cent decreases in average rainfall have boosted rice production by approximately 0.64 per cent in India. Furthermore, any positive shock in the carbon emission has a negative and significant impact on rice production at the 1 per cent level of significance in India. The estimated outcome indicates a rise in carbon emission in the atmosphere by 1 per cent, which reduces rice production by 6.16 per cent approximately. In comparison, carbon emission negative shocks positively impact rice production at the 1 per cent significance level. The coefficient of the negative component of carbon emission indicates that it increases rice production by 1.69 per cent when there is 1 per cent reduction in the carbon emission. We can infer from the estimated results that rice production has been boosted by reducing carbon emissions in India's atmosphere in the short run. Likewise, the impact of positive shock in the rural population has a negative and insignificant effect on rice production in the short run. Interpretively, a 1 per cent increase in rural population leads to decrease rice production by 0.50 per cent in India. Coefficients indicate that rice production decreases when increasing rural population. In comparison, negative shock in the rural population has positively influenced rice production by 1.82 per cent in the short-run at a 1 per cent level of significance.

Moving on to other controlled variables such as fertiliser consumption $(\operatorname{lnF})$, agricultural credit $(\ln A C)$, and area under crops on rice production $(\ln A U R)$, these are three core elements of rice production (Chandio et al. 2021). Our findings show that a 1 per cent increase in fertiliser consumption, agricultural credit and area under crop enhance rice production by 0.70 per cent, 0.04 per cent and 2.34 per cent, respectively, in India. These findings are consistent with previous 
494 studies (Chandio et al. 2021; Chandio et al. 2020; Janjua et al. 2014; Nasrullah et al. 2021; 495 Omoregie et al. 2018; Zakaria et al. 2020). In the context of India, agricultural credit plays a 496 significant role to boost agriculture production and farm income (Mohan 2006). Chandio et al. 497 (2021) found that agriculture credit has a positive and significant impact on rice production in 498 Nepal. Baig et al. (2020) state that fertiliser positively influenced rice production in India. Due to 499 might be the reason that fertiliser enhances soil fertility and nutrition, which create a considerable 500 positive impact on rice production (Janjua et al. 2014). Chandio et al. (2021) stated that the area 501 under crop positively impacts rice production in Turkey. The area under rice has the largest share 502 in India, which positively contribute to rice production. The negative and significant ECT value 503 shows that all the variables move towards long-run stability at a medium annual speed of 504 adjustment of 70.97 per cent.

Table 8. Cointegration Result (Dependent Variable: LNPR)

\begin{tabular}{|c|c|c|c|}
\hline Variables & Coefficient & Std. Error & Prob. \\
\hline Constant & $7.096 * * *$ & 0.412 & 0.003 \\
\hline $\operatorname{lnPR}$ & $-0.686 * *$ & 0.08 & 0.014 \\
\hline $\ln \mathrm{AT}^{+}$ & $-9.231 * * *$ & 0.392 & 0.002 \\
\hline $\ln \mathrm{AT}^{-}$ & $-10.32 * * *$ & 0.64 & 0.004 \\
\hline $\operatorname{lnRF^{+}}$ & $-1.247 * * *$ & 0.089 & 0.005 \\
\hline $\operatorname{lnRF^{-}}$ & $2.870 * * *$ & 0.158 & 0.003 \\
\hline $\operatorname{lnCO} 2^{+}$ & $-1.956 * * *$ & 0.93 & 0.002 \\
\hline $\operatorname{lnCO} 2^{-}$ & 0.421 & 0.004 & 0.581 \\
\hline $\mathrm{RP}^{+}$ & 0.492 & 0.3 & 0.172 \\
\hline $\mathrm{RP}^{-}$ & $-0.396 * * *$ & 0.139 & 0.001 \\
\hline$\Delta \operatorname{lnPR}$ & $-0.727 * * *$ & 0.042 & 0.003 \\
\hline$\Delta \ln \mathrm{AT}^{+}$ & $17.23 * * *$ & 0.661 & 0.001 \\
\hline$\Delta \ln \mathrm{AT}^{-}$ & $2.610 * *$ & 0.447 & 0.028 \\
\hline$\Delta \ln \mathrm{AT}^{-}(-1)$ & $-4.75 * * *$ & 0.43 & 0.008 \\
\hline$\Delta \operatorname{lnRF^{+}}$ & $-0.745^{* * *} *$ & 0.052 & 0.006 \\
\hline$\Delta \operatorname{lnRF^{+}(-1)}$ & $1.114 * * *$ & 0.585 & 0.003 \\
\hline$\Delta \operatorname{lnRF}^{-}$ & $0.647 * * *$ & 0.052 & 0.007 \\
\hline$\Delta \ln \operatorname{RF}^{-}(-1)$ & $-0.523 * *$ & 0.063 & 0.014 \\
\hline$\Delta \operatorname{lnCO} 2^{+}$ & $-6.163 * * *$ & 0.301 & 0.002 \\
\hline$\Delta \operatorname{lnCO} 2^{-}$ & 1.690 & 0.165 & 0.091 \\
\hline$\Delta \mathrm{RP}^{+}$ & -0.504 & 0.30 & 0.142 \\
\hline$\Delta \mathrm{RP}^{-}$ & $1.827 * * *$ & 0.084 & 0.002 \\
\hline
\end{tabular}




\begin{tabular}{|c|c|c|c|}
\hline$\Delta \mathrm{RP}^{-}(-1)$ & $-0.642 * *$ & 0.092 & 0.02 \\
\hline $\ln F$ & $0.709 * * *$ & 0.043 & 0.004 \\
\hline $\ln \mathrm{AC}$ & $0.0458 * * *$ & 0.002 & 0.004 \\
\hline $\ln A U R$ & $2.349 * * *$ & 0.166 & 0.005 \\
\hline ECT(-1) & $-0.7097 * * *$ & & \\
\hline R-squared & 0.99 & & \\
\hline $\operatorname{Adj}-R^{2}$ & 0.98 & & \\
\hline $\mathrm{L}_{\operatorname{lnAT}}{ }^{+}$ & $-13.64 * * *$ & $\mathrm{~L}_{\ln A \mathrm{~T}^{-}}$ & $\begin{array}{l}15.05 * * \\
*\end{array}$ \\
\hline $\mathrm{L}_{\operatorname{lnRF}}{ }^{+}$ & $-1.81 * *$ & $\mathrm{~L}_{\operatorname{lnRF}}{ }^{-}$ & $\begin{array}{l}-4.18 * * * \\
0.002 * *\end{array}$ \\
\hline $\mathrm{L}_{\operatorname{lnCO} 2}{ }^{+}$ & $-2.85 * * *$ & LlnCO2- & $*$ \\
\hline $\mathrm{LRP}^{+}$ & $0.001 * * *$ & LRP- & $0.57 * * *$ \\
\hline $\mathrm{W}_{\mathrm{LR}, \ln \mathrm{AT}}$ & $3.925 * * *$ & $\mathrm{~W}_{\mathrm{SR}, \ln \mathrm{AT}}$ & $\begin{array}{l}153.5 * * \\
*\end{array}$ \\
\hline $\mathrm{W}_{\mathrm{LR}, \operatorname{lnRF}}$ & $53.33 * * *$ & $\mathrm{~W}_{\mathrm{SR}, \operatorname{lnRF}}$ & $\begin{array}{l}8.95 * * * \\
329.4 * *\end{array}$ \\
\hline $\mathrm{W}_{\mathrm{LR}, \ln \mathrm{lO} 2}$ & $57.81 * * *$ & $\mathrm{~W}_{\mathrm{SR}, \operatorname{lnCO} 2}$ & $\begin{array}{l}* \\
575.5 * *\end{array}$ \\
\hline $\mathrm{W}_{\mathrm{LR}, \mathrm{RP}}$ & $58.59 * * *$ & $\begin{array}{l}\mathrm{W}_{\mathrm{SR}, \mathrm{RP}} \\
\quad 288.00 * *\end{array}$ & $*$ \\
\hline FPSS & & $*$ & \\
\hline $\mathrm{T}_{\mathrm{BDM}}$ & & $-8.47 * * *$ & \\
\hline
\end{tabular}

Sources: Calculated by authors. $* * * \mathrm{p}<0.01, * * \mathrm{p}<0.05, * \mathrm{p}<0.1$

507 Finally, we performed several dynamic adjustments, the results of which are given in Figure 4,

508 which depicts the cumulative dynamic multipliers. These multipliers depict the pattern of rice 509 production adjustment toward its new long-term equilibrium as a result of a negative or positive 510 unitary shock in rainfall, mean temperature, carbon emissions, and rural population, respectively. 511 The dynamic multipliers are computed using the AIC's best-fit NARDL model. A particular 512 prediction horizon's rice production adjustment to positive (green line) and negative (red line) 513 shocks is captured by the positive and negative curves. As seen in the graph, the asymmetric curve 514 (dashed red line) represents the difference between the dynamic multipliers for positive and 515 negative shocks, respectively. There is a 95 percent confidence interval between the lower and 516 upper bands (dotted red lines) of this curve. 


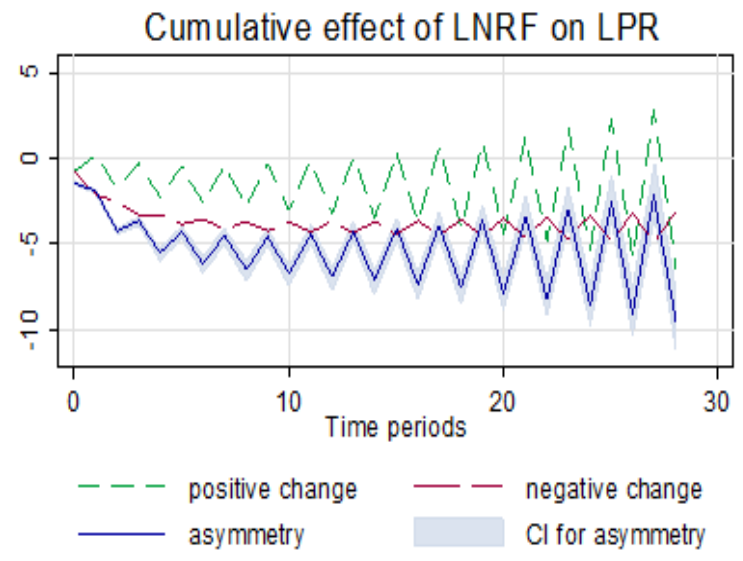

Note: $95 \%$ boottrap $\mathrm{Cl}$ is based on 100 replications

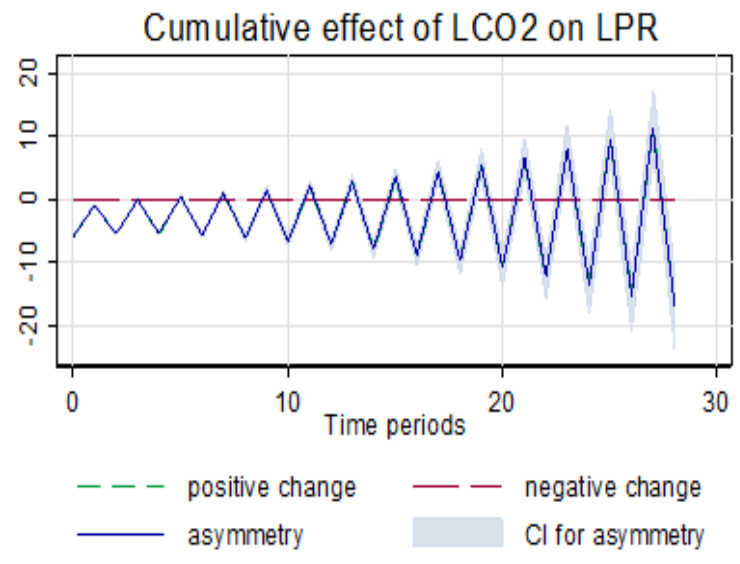

Note: $95 \%$ boottrap $\mathrm{Cl}$ is besed on 100 replications

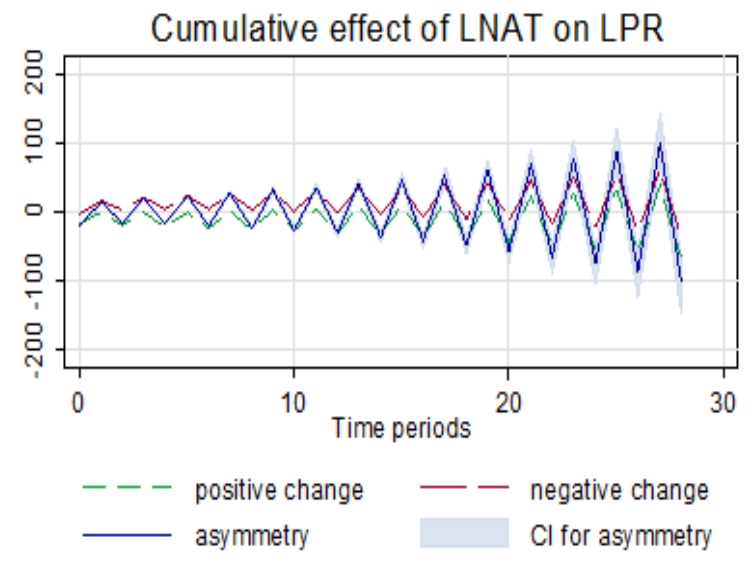

Note: $95 \%$ bootst ap $\mathrm{Cl}$ is based on 100 replications
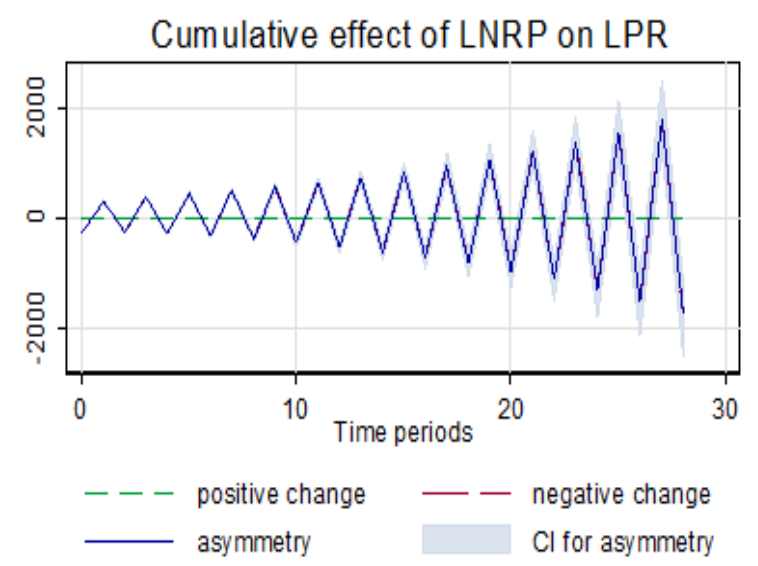

Note: $95 \%$ bootstrap $\mathrm{Cl}$ is based on 100 replications

Figure 4: Dynamic Multiplier Adjustment Graph

Figure 4 confirms a negative association between rainfall and rice output. A negative shock in rainfall outperforms a positive shock over the horizon. There is also a large asymmetric reaction to rainfall shocks. As with mean temperature, rice production is negatively correlated. This confirms the results in Table 8 that a negative shock in mean temperature dominates a positive shock in the long term. Furthermore, positive carbon emission shocks must outweigh beneficial effects on rice production for there to be a negative correlation. However, a negative shock in rural areas outweighs a positive one. Table 9 displays the results of different diagnostic tests used to assess the model's reliability (normality, autocorrelation, heteroscedasticity, and Ramsey RESET model). The NARDL model does not suffer from any diagnostic problem. CUSUM and 
529 CUSUMQ tests were used to assess model stability. In Fig. 5 (A \& B), the predicted line is within

530 the crucial values at the 5\% level of significance, indicating the model is highly stable.

531

Table 9. Result of Diagnostic Test

\begin{tabular}{lll}
\hline Diagnostic Test & Statistics & P-Value \\
Jarque-Bera & 2.08 & 0.35 \\
Auto Correlation & 8.03 & 0.7 \\
BPG Test & 0.21 & 0.64 \\
Ramsey Reset & 0.87 & 0.81 \\
\hline
\end{tabular}

Notes: BPG indicates Breusch/Pagan heteroskedasticity test

532

533

534

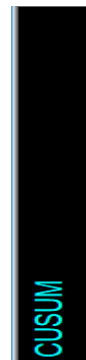

0
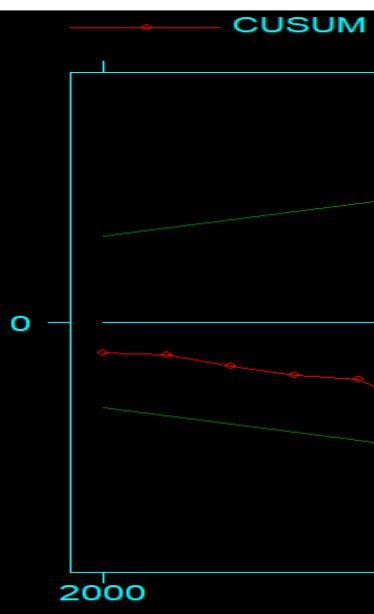

2000

Fig. 5 (A) Stability Model (CUSUM)

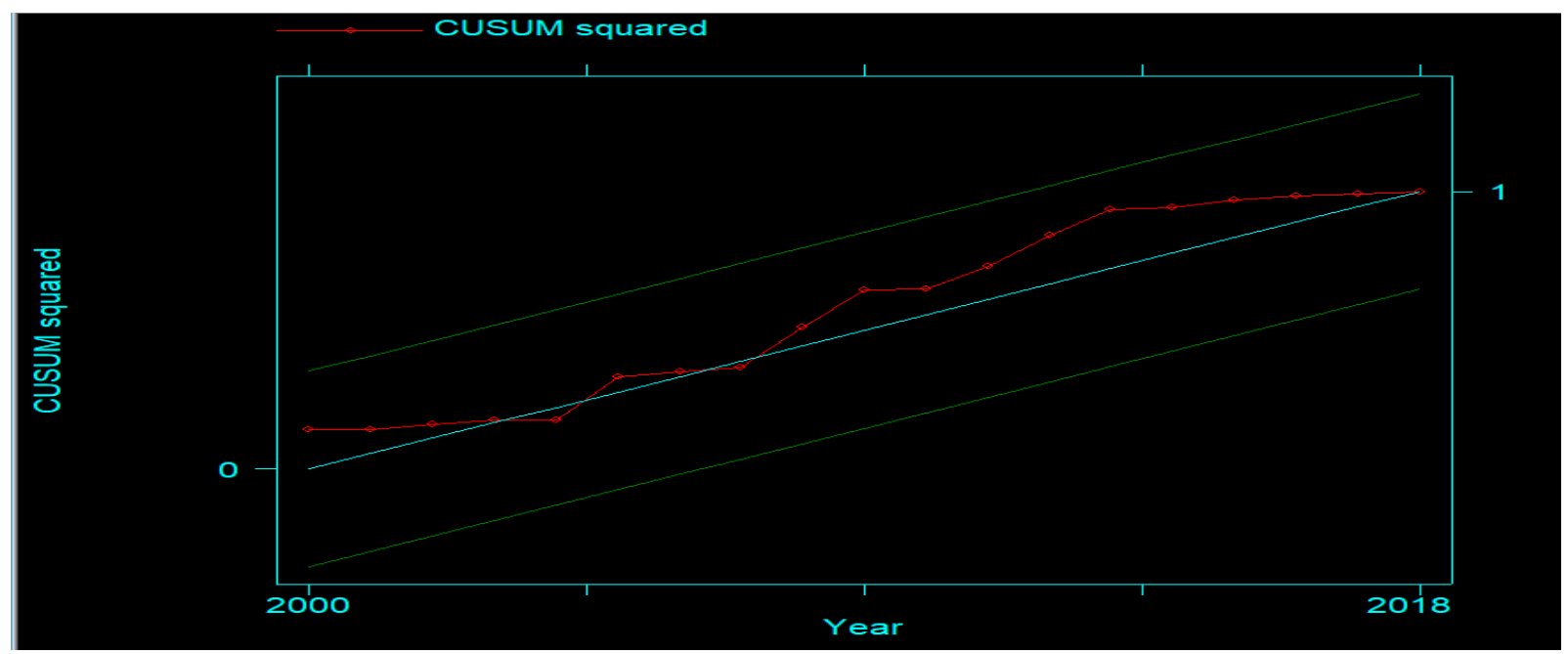




\section{Granger Causality Results}

Asymmetrical causality between dependent and independent variables are reported in Table 10.

540 We observed a bidirectional impact between a negative shock in rainfall and rice production. In contrast, one-way causality running from positive shock in rainfall to rice production. In addition,

542 we found bi-direction asymmetrical causality among mean temperature and rice production.

543 Furthermore, a two-way causal relationship exists between carbon emission (Positive and negative

544 shock) and rice production. Similarly, we found bidirectional asymmetrical causality running

545 among the rural population and rice production. However, bidirectional impact between fertiliser consumption and rice production while one-way causal nexus between area under crop and rice production. Meanwhile, no causal relation runs from agricultural credit to rice production. It implies that positive and negative shocks in mean temperature, carbon emission, and rural population will influence rice production and vice-versa. This work is in line with Chandio et al. (2021), who stated that average rainfall, consumption of fertiliser and agriculture credit has positively influenced production of rice in Nepal. This study contradicts Warsame et al. (2021), who argued that there is no causal relationship between average rainfall, mean temperature carbon emission and cereals crop production in Somalia. While negative shock in rainfall, fertiliser consumption and area under crop has granger causes rice production and vice versa.

555 Moreover, one-way causality flows from rainfall positive shock towards the area under crop to rice production. Furthermore, unidirectional causality also running from rice production to increasing carbon emission and agricultural credit, which indicates that increasing rice production will increase carbon emission and agricultural credit. In contrast, there is no asymmetrical causality running from average rainfall positive shock, a negative shock in carbon emissions, and a positive shock in agricultural credit to rice production. It indicates that increasing rainfall, decreasing 561 carbon emissions, and increasing agricultural credit has no significant impact on rice production.

562 Similarly, two-way causality exists between variables such as $\mathrm{LnRF}^{+} \Leftrightarrow \mathrm{LnRF}^{-}, \mathrm{LnRF}^{+}$ $\Leftrightarrow \ln \mathrm{AT}^{+}, \mathrm{LnRF}^{+} \Leftrightarrow 1 \mathrm{CO} 2^{+}, \mathrm{LnRF}^{+} \Leftrightarrow 1 \mathrm{CO} 2^{-}, \mathrm{LnRF}^{-} \Leftrightarrow \ln \mathrm{AT}^{+}, \mathrm{LnRF}^{+} \Leftrightarrow 1 \mathrm{CO} 2^{+}, \mathrm{LnRF}^{-}$

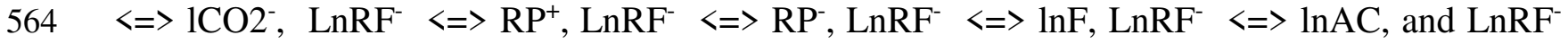

$565 \Leftrightarrow$ LAUR. While unidirectional causality running from postive and negative shock in rural 566 population, agricultural credit to increasing rainfall. Furthermore, two-way directional causality 
running between $\ln \mathrm{AT}^{+} \Leftrightarrow \mathrm{LnAT}^{-}, \ln \mathrm{AT}^{+} \Leftrightarrow 1 \mathrm{CO}^{+}, \ln \mathrm{AT}^{+} \Leftrightarrow \mathrm{RP}^{-}, \ln \mathrm{AT}^{+} \Leftrightarrow \ln \mathrm{AC}$ $\ln \mathrm{AT}^{+} \Leftrightarrow$ LAUR, $\ln \mathrm{AT}^{-} \Leftrightarrow 1 \mathrm{CO}^{+}, \ln \mathrm{AT}^{-} \Leftrightarrow 1 \mathrm{CO} 2^{-}$, and $\ln \mathrm{AT}^{-} \Leftrightarrow=$ LAUR. This findings is consistent with (Warsame et al. 2021), who stated that area under crop has positively influenced mean temperature in the atmosphere. Likewise, one-way causality running from increasing and decreasing temperature to increasing rural population, which indicates that increasing and decreasing temperature will positively influenced rural population. Furthermore, there is also evidence that decreasing temperature $\left(\mathrm{LnAT}^{-}\right)$will increase fertilizer consumption $(\operatorname{lnF})$ and agricultural credit $(\ln A C)$.

Moreover, at 1 per cent significance level asymmetrical causality between decreasing carbon emission and increasing rural population which indicates reducing carbon emission leads to the increase in rural population. Apart from, one-way directional causality running from increasing rural population to increasing carbon emission means that increasing population leads to decrease environmental quality in the atmosphere. Population increase in rural areas leads to increase deforestation, which play a key role to deteriorate environmental quality. Researchers stated that the rising population is a dominant cause of environmental degradation (Abbas et al. 2021).

However, evidence shows that causality runs from increasing and decreasing carbon emissions towards fertiliser consumption and agricultural credit at the 1 per cent level of significance. The outcome indicates that increasing and decreasing carbon emissions has influenced fertiliser consumption. The causal relationship between agricultural credit and decreasing carbon emission demonstrates that unidirectional causality running from agricultural credit towards decreasing carbon emission at 5 levels of significance, which indicates that increasing agricultural credit leads to increase environmental quality in the atmosphere. Asymmetrical causality exists between increasing carbon emission and area under crop, which suggests that increasing carbon emission leads to the increasing area under crop and vice-versa. Unidirectional asymmetrical causality also running from decreasing carbon emission towards the area under crop at the 1 level of significance.

Table 10 :Result of Granger Causality Test

F-Statisics Prob. Result

\begin{tabular}{llllll}
\hline $\ln \mathrm{RF}^{+}$ & $\neq>$ & $\operatorname{lnPR}$ & 5.306 & 0.070 & Rejected \\
$\ln \mathrm{PR}$ & $\neq>$ & $\operatorname{lnRF^{+}}$ & 2.465 & 0.292 & Accepted
\end{tabular}




\begin{tabular}{|c|c|c|c|c|c|}
\hline $\ln \mathrm{RF}^{-}$ & $\neq>$ & $\operatorname{lnPR}$ & 151.900 & 0.000 & Rejected \\
\hline $\ln P R$ & $\neq>$ & $\ln \mathrm{RF}^{-}$ & 11.316 & 0.003 & Rejected \\
\hline $\ln \mathrm{AT}^{+}$ & $\neq>$ & $\operatorname{lnPR}$ & 47.324 & 0.000 & Rejected \\
\hline $\operatorname{lnPR}$ & $\neq>$ & $\ln \mathrm{AT}^{+}$ & 25.970 & 0.000 & Rejected \\
\hline $\ln \mathrm{AT}^{-}$ & $\neq>$ & $\operatorname{lnPR}$ & 8.623 & 0.013 & Rejected \\
\hline $\operatorname{lnPR}$ & $\neq>$ & $\ln \mathrm{AT}^{-}$ & 59.598 & 0.000 & Rejected \\
\hline $\operatorname{lnCO} 2^{+}$ & $\neq>$ & $\operatorname{lnPR}$ & 23.220 & 0.000 & Rejected \\
\hline $\ln P R$ & $\neq>$ & $\ln \mathrm{CO}_{2}{ }^{+}$ & 82.799 & 0.000 & Rejected \\
\hline $\operatorname{lnCO} 2^{-}$ & $\neq>$ & $\ln P R$ & 45.560 & 0.310 & Accepted \\
\hline $\ln P R$ & $\neq>$ & $\operatorname{lnCO} 2^{-}$ & 92.540 & 0.000 & Rejected \\
\hline $\mathrm{RP}^{+}$ & $\neq>$ & $\operatorname{lnPR}$ & 20.475 & 0.000 & Rejected \\
\hline $\ln P R$ & $\neq>$ & $\mathrm{RP}^{+}$ & 27.425 & 0.000 & Rejected \\
\hline $\mathrm{RP}^{-}$ & $\neq>$ & $\ln P R$ & 17.238 & 0.000 & Rejected \\
\hline $\operatorname{lnPR}$ & $\neq>$ & $\mathrm{RP}^{-}$ & 45.742 & 0.000 & Rejected \\
\hline $\ln F$ & $\neq>$ & $\operatorname{lnPR}$ & 25.882 & 0.000 & Rejected \\
\hline $\ln P R$ & $\neq>$ & $\ln F$ & 27.880 & 0.000 & Rejected \\
\hline $\ln A C$ & $\neq>$ & $\operatorname{lnPR}$ & 3.286 & 0.193 & Accepted \\
\hline $\ln P R$ & $\neq>$ & $\ln A C$ & 11.394 & 0.003 & Rejected \\
\hline InAUR & $\neq>$ & $\ln P R$ & 162.650 & 0.000 & Rejected \\
\hline $\ln P R$ & $\neq>$ & $\ln A U R$ & 0.484 & 0.785 & Accepted \\
\hline $\ln \mathrm{RF}^{+}$ & $\neq>$ & $\ln \mathrm{RF}^{-}$ & 118.850 & 0.000 & Rejected \\
\hline $\ln \mathrm{RF}^{-}$ & $\neq>$ & $\ln R F^{+}$ & 67.221 & 0.000 & Rejected \\
\hline $\ln \mathrm{RF}^{+}$ & $\neq>$ & $\ln \mathrm{AT}^{+}$ & 112.700 & 0.000 & Rejected \\
\hline $\ln \mathrm{AT}^{+}$ & $\neq>$ & $\ln R F^{+}$ & 206.620 & 0.000 & Rejected \\
\hline $\ln \mathrm{RF}^{-}$ & $\neq>$ & $\ln \mathrm{AT}^{+}$ & 105.550 & 0.000 & Rejected \\
\hline $\ln \mathrm{AT}^{+}$ & $\neq>$ & $\ln \mathrm{RF}^{-}$ & 155.480 & 0.000 & Rejected \\
\hline $\ln R F^{+}$ & $\neq>$ & $\operatorname{lnCO} 2^{+}$ & 44.896 & 0.000 & Rejected \\
\hline
\end{tabular}




\begin{tabular}{|c|c|c|c|c|c|}
\hline $\operatorname{lnCO} 2^{+}$ & $\neq>$ & $\ln \mathrm{RF}^{+}$ & 21.851 & 0.000 & Rejected \\
\hline $\mathrm{LnRF}^{-}$ & $\neq>$ & $\operatorname{lnCO} 2^{+}$ & 239.350 & 0.000 & Rejected \\
\hline $\operatorname{lnCO} 2^{+}$ & $\neq>$ & $\operatorname{lnRF}{ }^{-}$ & 23.968 & 0.000 & Rejected \\
\hline $\operatorname{lnRF} F^{+}$ & $\neq>$ & $\operatorname{lnCO} 2^{-}$ & 34.568 & 0.000 & Rejected \\
\hline $\operatorname{lnCO} 2^{-}$ & $\neq>$ & $\mathrm{LnRF}^{+}$ & 15.456 & 0.000 & Rejected \\
\hline $\operatorname{lnRF}{ }^{-}$ & $\neq>$ & $\operatorname{lnCO} 2^{-}$ & 18.547 & 0.000 & Rejected \\
\hline $\operatorname{lnCO} 2^{-}$ & $\neq>$ & $\operatorname{lnRF^{-}}$ & 24.411 & 0.000 & Rejected \\
\hline $\operatorname{lnRF} F^{+}$ & $\neq>$ & $\mathrm{RP}^{+}$ & 36.487 & 0.000 & Rejected \\
\hline $\mathrm{RP}^{+}$ & $\neq>$ & $\ln \mathrm{RF}^{+}$ & 10.254 & 0.140 & Accepted \\
\hline $\operatorname{lnRF} F^{+}$ & $\neq>$ & $\mathrm{RP}^{-}$ & 79.799 & 0.000 & Rejected \\
\hline $\mathrm{RP}^{-}$ & $\neq>$ & $\ln \mathrm{RF}^{+}$ & 3.126 & 0.450 & Accepted \\
\hline $\ln \mathrm{RF}^{-}$ & $\neq>$ & $\mathrm{RP}^{+}$ & 41.124 & 0.000 & Rejected \\
\hline $\mathrm{RP}^{+}$ & $\neq>$ & $\ln \mathrm{RF}^{-}$ & 16.245 & 0.033 & Rejected \\
\hline $\ln \mathrm{RF}^{-}$ & $\neq>$ & $\mathrm{RP}^{-}$ & 31.100 & 0.000 & Rejected \\
\hline $\mathrm{RP}^{-}$ & $\neq>$ & $\ln \mathrm{RF}^{-}$ & 6.849 & 0.033 & Rejected \\
\hline $\ln \mathrm{RF}^{+}$ & $\neq>$ & $\ln F$ & 50.609 & 0.000 & Rejected \\
\hline $\ln F$ & $\neq>$ & $\ln R F^{+}$ & 10.561 & 0.005 & Rejected \\
\hline $\operatorname{lnRF^{-}}$ & $\neq>$ & $\ln F$ & 144.400 & 0.000 & Rejected \\
\hline $\ln F$ & $\neq>$ & $\ln \mathrm{RF}^{-}$ & 5.009 & 0.082 & Rejected \\
\hline $\operatorname{lnRF} F^{+}$ & $\neq>$ & $\ln A C$ & 13.220 & 0.001 & Rejected \\
\hline $\ln A C$ & $\neq>$ & $\operatorname{lnRF^{+}}$ & 0.845 & 0.655 & Accepted \\
\hline $\ln R F^{-}$ & $\neq>$ & $\ln A C$ & 112.530 & 0.000 & Rejected \\
\hline $\ln A C$ & $\neq>$ & $\ln \mathrm{RF}^{-}$ & 34.865 & 0.000 & Rejected \\
\hline $\operatorname{lnRF}+$ & $\neq>$ & $\ln \mathrm{AUR}$ & 105.860 & 0.000 & Rejected \\
\hline lnAUR & $\neq>$ & $\ln R F+$ & 17.338 & 0.000 & Rejected \\
\hline $\ln R F^{-}$ & $\neq>$ & $\ln A U R$ & 31.726 & 0.000 & Rejected \\
\hline lnAUR & $\neq>$ & $\operatorname{lnRF^{-}}$ & 29.127 & 0.000 & Rejected \\
\hline
\end{tabular}




\begin{tabular}{|c|c|c|c|c|c|}
\hline $\ln \mathrm{AT}^{+}$ & $\neq>$ & $\ln \mathrm{AT}^{-}$ & 157.740 & 0.000 & Rejected \\
\hline $\ln \mathrm{AT}^{-}$ & $\neq>$ & $\ln \mathrm{AT}^{+}$ & 38.469 & 0.000 & Rejected \\
\hline $\ln \mathrm{AT}^{+}$ & $\neq>$ & $\operatorname{lnCO} 2^{+}$ & 51.393 & 0.000 & Rejected \\
\hline $\operatorname{lnCO} 2^{+}$ & $\neq>$ & $\ln \mathrm{AT}^{+}$ & 17.843 & 0.000 & Rejected \\
\hline $\ln \mathrm{AT}^{+}$ & $\neq>$ & $\operatorname{lnCO} 2^{-}$ & 25.452 & 0.124 & Accepted \\
\hline $\operatorname{lnCO} 2^{-}$ & $\neq>$ & $\ln \mathrm{AT}^{+}$ & 12.687 & 0.541 & Accepted \\
\hline $\ln \mathrm{AT}^{-}$ & $\neq>$ & $\operatorname{lnCO} 2^{+}$ & 22.442 & 0.000 & Rejected \\
\hline $\operatorname{lnCO} 2^{+}$ & $\neq>$ & $\ln \mathrm{AT}^{-}$ & 19.493 & 0.000 & Rejected \\
\hline $\ln \mathrm{AT}^{-}$ & $\neq>$ & $\operatorname{lnCO} 2^{-}$ & 31.258 & 0.009 & Rejected \\
\hline $\operatorname{lnCO} 2^{-}$ & $\neq>$ & $\mathrm{LnAT}^{-}$ & 29.874 & 0.000 & Rejected \\
\hline $\ln \mathrm{AT}^{+}$ & $\neq>$ & $\mathrm{RP}^{+}$ & 51.487 & 0.145 & Accepted \\
\hline $\mathrm{RP}^{+}$ & $\neq>$ & $\ln \mathrm{AT}^{+}$ & 34.897 & 0.001 & Rejected \\
\hline $\ln \mathrm{AT}^{+}$ & $\neq>$ & $\mathrm{RP}^{-}$ & 93.946 & 0.000 & Rejected \\
\hline $\mathrm{RP}^{-}$ & $\neq>$ & $\ln \mathrm{AT}^{+}$ & 22.796 & 0.000 & Rejected \\
\hline $\ln \mathrm{AT}^{-}$ & $\neq>$ & $\mathrm{RP}^{+}$ & 23.478 & 0.005 & Rejected \\
\hline $\mathrm{RP}^{+}$ & $\neq>$ & $\ln \mathrm{AT}^{-}$ & 14.369 & 0.451 & Accepted \\
\hline $\ln \mathrm{AT}^{+}$ & $\neq>$ & $\ln F$ & 100.800 & 0.000 & Rejected \\
\hline $\ln F$ & $\neq>$ & $\ln \mathrm{AT}^{+}$ & 1.907 & 0.385 & Accepted \\
\hline $\ln \mathrm{AT}^{-}$ & $\neq>$ & $\ln F$ & 12.921 & 0.002 & Rejected \\
\hline $\ln F$ & $\neq>$ & $\ln \mathrm{AT}^{-}$ & 0.923 & 0.630 & Accepted \\
\hline $\ln \mathrm{AT}^{+}$ & $\neq>$ & $\ln A C$ & 65.634 & 0.000 & Rejected \\
\hline $\ln A C$ & $\neq>$ & $\ln \mathrm{AT}^{+}$ & 5.367 & 0.068 & Rejected \\
\hline LnAT $^{-}$ & $\neq>$ & $\ln A C$ & 5.818 & 0.055 & Rejected \\
\hline $\ln A C$ & $\neq>$ & $\ln \mathrm{AT}^{-}$ & 1.430 & 0.489 & Accepted \\
\hline $\ln \mathrm{AT}^{+}$ & $\neq>$ & $\ln A U R$ & 251.070 & 0.000 & Rejected \\
\hline $\ln A U R$ & $\neq>$ & $\ln \mathrm{AT}^{+}$ & 103.650 & 0.000 & Rejected \\
\hline $\ln \mathrm{AT}^{-}$ & $\neq>$ & lnAUR & 26.626 & 0.000 & Rejected \\
\hline
\end{tabular}




\begin{tabular}{|c|c|c|c|c|c|}
\hline $\ln A U R$ & $\neq>$ & $\ln \mathrm{AT}^{-}$ & 174.970 & 0.000 & Rejected \\
\hline $\operatorname{lnCO} 2^{+}$ & $\neq>$ & $\operatorname{lnCO} 2^{-}$ & 87.925 & 0.000 & Rejected \\
\hline $\operatorname{lnCO} 2^{-}$ & $\neq>$ & $\operatorname{lnCO} 2^{+}$ & 60.874 & 0.001 & Rejected \\
\hline $\operatorname{lnCO} 2^{+}$ & $\neq>$ & $\mathrm{RP}^{+}$ & 12.547 & 0.124 & Accepted \\
\hline $\mathrm{RP}^{+}$ & $\neq>$ & $\operatorname{lnCO} 2^{+}$ & 24.571 & 0.002 & Rejected \\
\hline $\operatorname{lnCO} 2^{-}$ & $\neq>$ & $\mathrm{RP}^{+}$ & 92.478 & 0.004 & Rejected \\
\hline $\mathrm{RP}^{+}$ & $\neq>$ & $\operatorname{lnCO} 2^{-}$ & 34.142 & 0.110 & Accepted \\
\hline $\operatorname{lnCO} 2^{+}$ & $\neq>$ & $\ln F$ & 25.990 & 0.000 & Rejected \\
\hline $\ln F$ & $\neq>$ & $\operatorname{lnCO} 2^{+}$ & 2.456 & 0.293 & Accepted \\
\hline $\operatorname{lnCO} 2^{-}$ & $\neq>$ & $\operatorname{lnF}$ & 15.412 & 0.003 & Rejected \\
\hline $\ln F$ & $\neq>$ & $\operatorname{lnCO} 2^{-}$ & 43.258 & 0.150 & Accepted \\
\hline $\operatorname{lnCO} 2^{+}$ & $\neq>$ & $\ln A C$ & 22.286 & 0.000 & Rejected \\
\hline $\ln A C$ & $\neq>$ & $\operatorname{lnCO} 2^{+}$ & 2.841 & 0.242 & Accepted \\
\hline $\operatorname{lnCO} 2^{-}$ & $\neq>$ & $\ln A C$ & 75.142 & 0.145 & Accepted \\
\hline $\ln A C$ & $\neq>$ & $\operatorname{lnCO} 2^{-}$ & 25.197 & 0.051 & Rejected \\
\hline $\operatorname{lnCO} 2^{+}$ & $\neq>$ & $\ln \mathrm{AUR}$ & 7.234 & 0.027 & Rejected \\
\hline lnAUR & $\neq>$ & $\operatorname{lnCO} 2^{+}$ & 159.890 & 0.000 & Rejected \\
\hline $\operatorname{lnCO} 2^{-}$ & $\neq>$ & $\ln A U R$ & 14.589 & 0.156 & Accepted \\
\hline $\ln A U R$ & $\neq>$ & $\operatorname{lnCO} 2^{-}$ & 102.741 & 0.187 & Accepted \\
\hline $\mathrm{RP}^{+}$ & $\neq>$ & $\mathrm{RP}^{-}$ & 99.457 & 0.007 & Rejected \\
\hline $\mathrm{RP}^{-}$ & $\neq>$ & $\mathrm{RP}^{+}$ & 24.175 & 0.001 & Rejected \\
\hline $\mathrm{RP}^{+}$ & $\neq>$ & $\ln F$ & 12.871 & 0.000 & Rejected \\
\hline $\ln F$ & $\neq>$ & $\mathrm{RP}^{+}$ & 48.545 & 0.841 & Accepted \\
\hline $\mathrm{RP}^{-}$ & $\neq>$ & $\ln F$ & 21.506 & 0.000 & Rejected \\
\hline $\ln F$ & $\neq>$ & $\mathrm{RP}^{-}$ & 6.664 & 0.036 & Rejected \\
\hline $\mathrm{RP}^{+}$ & $\neq>$ & $\ln A C$ & 56.471 & 0.090 & Rejected \\
\hline $\ln A C$ & $\neq>$ & $\mathrm{RP}^{+}$ & 102.587 & 0.005 & Rejected \\
\hline
\end{tabular}




$\begin{array}{llllll}\mathrm{RP}^{-} & \neq> & \ln \mathrm{AC} & 12.421 & 0.002 & \text { Rejected } \\ \ln \mathrm{AC} & \neq> & \mathrm{RP}^{-} & 19.815 & 0.000 & \text { Rejected } \\ \mathrm{RP}^{+} & \neq> & \ln \mathrm{AUR} & 21.457 & 0.142 & \text { Accepted } \\ \ln \mathrm{AUR} & \neq> & \mathrm{RP}^{+} & 8.547 & 0.751 & \text { Accepted } \\ \mathrm{RP} & \neq> & \ln \mathrm{AUR} & 0.031 & 0.985 & \text { Accepted } \\ \ln \mathrm{AUR} & \neq> & \mathrm{RP} & 84.564 & 0.000 & \text { Rejected } \\ \operatorname{lnF} & \neq> & \ln \mathrm{AC} & 7.670 & 0.022 & \text { Rejected } \\ \ln \mathrm{AC} & \neq> & \operatorname{lnF} & 6.376 & 0.041 & \text { Rejected } \\ \operatorname{lnF} & \neq> & \ln \mathrm{AUR} & 10.500 & 0.005 & \text { Rejected } \\ \ln \mathrm{AUR} & \neq> & \ln \mathrm{F} & 81.095 & 0.000 & \text { Rejected } \\ \ln \mathrm{AC} & \neq> & \ln \mathrm{AUR} & 18.191 & 0.000 & \text { Rejected } \\ \ln \mathrm{AUR} & \neq> & \ln \mathrm{AC} & 75.941 & 0.000 & \text { Rejected }\end{array}$

\section{Conclusion and Policy Implications}

595 In India, the rice crop has a crucial role in agricultural growth and food security. Rice is a staple 596 food for India's people; more than 50 per cent population consumed rice crops once a day. Rice 597 crop has widely grown, followed by the wheat, coarse cereals and pulse in India. This study's 598 primary purpose is to investigate the asymmetrical relationship and granger causality between 599 climate change and rice production through nonlinear ARDL using time series data spanning from 600 1991-2018 in India. The outcomes confirm the presence of asymmetric relationships among 601 selected variables in the short and long run.

602 The findings reveal that increasing and decreasing temperature influenced rice production 603 adversely in the long run while positively affected in the short run by different magnitude. 604 However, excess rainfall has adversely affected rice production, while a decrease in rainfall has 605 no evidence of an adverse effect on rice production in the long and short run. Furthermore, in the 606 long and short run, increased carbon emission levels in the atmosphere had impeded rice 607 production. In contrast, decrease carbon emissions had no adverse impact on rice production. In 608 the long and short run, positive shock in the rural population has positively affected rice 
609 production, while negative shock has adversely affected rice production. The estimated outcome

610 indicates that other controlled variables such as fertiliser consumption, agricultural credit, and area

611 under crop have positively affected rice production in India.

612 The result from asymmetrical causality divulges a feedback effect between negative shock rainfall

613 and rice production. At the same time, a one-way direction causal relationship runs from positive

614 shock in rainfall towards rice production. Furthermore, there is a two-way directional causal

615 relationship between a positive and negative shock in mean temperature and rice production. At

616 the same time, there is no causal relationship between mean temperature and decreasing carbon

617 emission. Moreover, there is a feedback effect between increasing carbon emission and rice

618 production, while a one-way causal relationship runs from rice production to decreasing carbon

619 emission. However, we observed the two-way directional causal relationship among a positive and

620 negative shock in rural population and rice production. Likewise, a two-way causal relationship

621 runs between fertiliser consumption and rice production, while a one-way causal relationship runs

622 from rice production to agricultural credit and from the area under crop to rice production.

623 Based on our empirical investigations, some key policy implications emerged. Specifically, the

624 government should promote mechanisms of research and development to meet the demand of the

625 population. In this regard, the new fertilisers are required to produce and provided at a subsidised

626 rate to the farmers. To sustain rice production, improve irrigation infrastructure through increasing

627 public investment and develope climate-resilient seeds varieties to cope with or adapt to climate

628 change. Along with, at the district level government should provide proper training to farmers

629 regarding the usage of pesticides, a proper amount of fertiliser and irrigation systems. This study

630 was conducted at the national level and undertaken only on rice production, which cannot explain

631 the main influence of climate change or unlike the agro-environment region. However, to tackle

632 regional disparities and season wise production (Rabi or Kharif) into consideration, should perform

633 area-specific and season-specific research for better insight.

634 Authors' contributions

635 Imran Ali Baig: Conceptualization, Data curation, Formal analysis, Writing - original draft

636 Abbas Ali Chandio: Supervision

637 Ilhan Ozturk: Editing and Validation, Supervision

638 Pushp Kumar: Methodology, Investigation, Formal analysis

639 Zeeshan Anis Khan and Md. Abdus Salam: Review, Editing and made suggestions 


\section{Data availability}

641 Data will be made available upon request

642 Conflict of interest

643 We do not have any conflict of interest.

644 Funding

645 No funding was received from conducting this study.

646 Ethical Approval

647 Not applicable

648 Consent to Participate

649 Not applicable

650 Consent to Publish

651 Not applicable

652 References

653 Abbas S, Kousar S, Yaseen M, Mayo Z A, Zainab M, Mahmood M J, Raza H (2020) Impact assessment of Socioeconomic factors of dimensions of environmental degradation in Pakistan, SN Applied Science, 2, 468. | https://doi.org/10.1007/s42452-020-2231-4

Abbas S, Kousar S, Shirazi S A, Yaseen M, Latif Y (2021) Illuminating Empirical Evidence of Climate Change: Impacts on Rice Production in the Punjab Regions, Pakistan Agricultural Research https://doiorg/101007/s40003-021-00548-w

Abbas, Shujaat (2020) Climate change and cotton production: an empirical investigation of Pakistan Environmental Science and Pollution Research, 27(23), 29580-29588

662

663

664

665

666

667

668

669

670 https://doiorg/101007/s11356-020-09222-0

Ahsan F, Chandio A A, Fang W (2020) Climate change impacts on cereal crops production in Pakistan: Evidence from cointegration analysis International Journal of Climate Change Strategies and Management, 12(2), 257-269 https://doiorg/101108/IJCCSM-04-2019-0020

Alharthi M, Dogan E, Taskin D (2021) Analysis of CO2 emissions and energy consumption by sources in MENA countries: evidence from quantile regressions Environmental Science and Pollution Research, 28, 38901-38908 https://doiorg/101007/s11356-021-13356-0

Attiaoui I, Boufateh T (2019) Impact of climate change on cereal farming in Tunisia: A panel ARDL- PMG approach, Environmental Science and Pollution Research. 26 (Jan),pp.13334-13345. 
Auffhammer M, Ramanathan V, Jeffrey R, 2012. "Climate Change, the Mansoon, and Rice Yield in India." Climatic Change 111(2):411-24

Bahl P N (2015) Climate Change and Pulses: Approaches to Combat Its Impact Agricultural Research, 4(2), 103-108 https://doiorg/101007/s40003-015-0163-9

Baig I A, Ahmed F, Salam M A \& Khan S M (2020) An assessment of Climate change and Crop Productivity in India: A Multivariate Cointegration Framework TEST Engineering \& Management, 83, 3438-3452

Below, T, Artner, A, Siebert, R, \& Seiber, S (2010) Micro-level Practices to Adapt to Climate Change for African Small-scale Farmers: a review of selected literature In IFPRI discussion paper (Vol 0953, Issue February)

Bhanumurthy K, Kumar, L (2018) Climate Change and Agriculture in India: Studying Long-Term Patterns in Temperature, Rainfall and Agriculture Output Management and Economics Research Journal, 4(S2), 156-173

Bhatla, R, Ghosh, S, Verma, S, Mall, R K, Gharde, G R (2019) Variability of Monsoon Over Homogeneous Regions of India Using Regional Climate Model and Impact on Crop Production Agricultural Research, 8(3), 331-346 https://doiorg/101007/s40003-018-0368-9

Birthal, P S, Khan, T, Negi, D S, Agarwal, S (2014) Impact of Climate Change on Yields of Major Food Crops in India: Implications for Food Security 27(2), 145-155 https://doiorg/105958/0974-02792014000196

Chandio, A A, Jiang, Y, Abbas, Q, Amin, A (2020) Does financial development enhance agricultural production in the long-run? Evidence from China Journal of Public Affairs, September https://doiorg/101002/pa2342

Chandio, A A, Jiang, Y, Ahmad, F, Adhikari, S, Ain, Q (2021) Assessing the impacts of climatic and technological factors on rice production: Empirical evidence from Nepal Technology in Society, 66(May), 101607 https://doiorg/101016/jtechsoc2021101607

Chandio, Abbas Ali, Akram, W, Ahmad, F, Ahmad, M (2020) Dynamic relationship among agriculture-energy-forestry and carbon dioxide (CO2) emissions: empirical evidence from China Environmental Science and Pollution Research, 27(27), 34078-34089 https://doiorg/101007/s11356-020-09560-z

Chandio, Abbas Ali, Gokumenglu, K K, Ahmad, F (2021) Addressing the long- and short-run effects of climate change on major food crops production in Turkey. Environmental Science 
and Pollution Research, https://doiorg/https://doiorg/101007/s11356-021-14358-8

Chandio, Abbas Ali, Jiang, Y, Rauf, A, Ahmad, F, Amin, W, Shehzad, K (2020) Assessment of formal credit and climate change impact on agricultural production in Pakistan: A time series ARDL modelling approach Sustainability (Switzerland), 12(13) https://doiorg/103390/su12135241

Chandio, Abbas Ali, Magsi, H, Ozturk, I (2020) Examining the effects of climate change on rice production: a case study of Pakistan Environmental Science and Pollution Research, 27(8), 7812-7822 https://doiorg/101007/s11356-019-07486-9

Chandio, Abbas Ali, Ozturk, I, Akram, W, Ahmad, F, Mirani, A (2020) Empirical analysis of climate change factors affecting cereal yield : evidence from Turkey Environmental Science and Pollution Research, 27, 11944-11957 https://doiorg/https://doiorg/101007/s11356-02007739-y

Chavas, D R, Ce, R, Thomson, A M, Gao, X (2009) Long-term climate change impacts on agricultural productivity in eastern China Agricultural and Forest Meteorology, 149, 11181128 https://doiorg/101016/jagrformet200902001

Coulibaly Thierry, Moinul Islam, Shunsuke Managi. 2020. "The Impacts of Climate Change on Agriculture in African Countries.” Economics of Disasters and Climate Change 38(4):68594.

Dogan E, Inglesi-Lotz, R (2020) The impact of economic structure to the environmental Kuznets curve (EKC) hypothesis: evidence from European countries. Environmental Science and Pollution Research, 27(11), 12717-12724 https://doiorg/101007/s11356-020-07878-2

Fezzi C, Bateman I (2016) The Impact of Climate Change on Agriculture: Nonlinear Effects and Aggregation Bias in Ricardian Models of Farmland Values. Journal of the Association of Environmental and Resource Economists, 2(1), 57-92

Guntukula R (2019) Assessing the impact of climate change on Indian agriculture : Evidence from major crop yields Journal of Public Affairs, October, 1-7 https://doiorg/101002/pa2040

Gupta R, Mishra A (2019) Climate change-induced impact and uncertainty of rice yield of agroecological zones of India Agricultural Systems, 173(February), 1-11 https://doiorg/101016/jagsy201901009

Haile M G, Wossen T, Tesfaye K, Von Braun, J (2017) Impact of Climate Change, Weather Extremes, and Price Risk on Global Food Supply. Economics of Disasters and Climate 
Change, 1(1), 55-75 https://doiorg/101007/s41885-017-0005-2

Haris A A, Bhatt B P, Chhabra V, Biswas S, Elanchezhian R (2013) Climate Change Impacts on Yields of Phenologically Different Rice Varieties Over a Sub-Humid Climatic Environment. Agricultural Research, 2(4), 319-329 https://doiorg/101007/s40003-013-0079-1

Jan I, Ashfaq M, Chandio A A (2021) Impacts of climate change on yield of cereal crops in the northern climatic region of Pakistan. Environmental Science and Pollution Research https://doiorg/101007/s11356-021-14954-8

Janjua P, Samad G, Khan N (2014) Climate Change and Wheat Production in Pakistan : An Autoregressive Distributed Lag Approach NJAS - Wageningen Journal of Life Sciences, 68, 13-19 https://doiorg/101016/jnjas201311002

Kabubo-Mariara J, Karanja F K (2007) The economic impact of climate change on Kenyan crop agriculture: A Ricardian approach. Global and Planetary Change, 57, 319-330 https://doiorg/101016/jgloplacha200701002

Khanal U, Wilson C, Hoang V, Lee B (2018) Farmers ' Adaptation to Climate Change, Its Determinants and Impacts on Rice Yield in Nepal. Ecological Economics, 144(July 2017), 139-147 https://doiorg/101016/jecolecon201708006

Klutse N A B, Quagraine K A, Nkrumah F, Quagraine K T, Berkoh-Oforiwaa R, Dzrobi J F, Sylla M B (2021) The Climatic Analysis of Summer Monsoon Extreme Precipitation Events over West Africa in CMIP6 Simulations. Earth Systems and Environment https://doiorg/101007/s41748-021-00203-y

Korres N E, Norsworthy J K, Burgos N R, Oosterhuis, D M (2017) Temperature and drought impacts on rice production: An agronomic perspective regarding short- and long-term adaptation measures. Water Resources and Rural Development, 9, 12-27 https://doiorg/101016/jwrr201610001

Kumar A, Singh J, Sharma P (2020) Assessing the Climate Change Impact on Rice and Wheat Production in Uttar Pradesh and Haryana States of India Climate Change, 6(21)

Kumar, K S K (2011) Climate sensitivity of Indian agriculture : do spatial effects matter? Cambridge Journal of Regions, Economy and Society, 4(March), 221-235 https://doiorg/101093/cjres/rsr004

Kumar P, Sahu N C, Kumar S, Ansari, M A (2021) Impact of climate change on cereal production : evidence from lower-middle-income countries. Environmental Science and Pollution 
Research, 28(17) https://doiorg/https://doiorg/101007/s11356-021-14373-9

Lal M, Rathore L, Anapalli S (1998) Vulnerability of rice and wheat yields in NW India to future changes in climate Agricultural and Forest Meteorology, 89(February), 101-114 https://doiorg/101016/S0168-1923(97)00064-6

Masud M, Rahman S, Al-Amin A, Kari F, Filho W (2014) Impact of climate change : an empirical investigation of Malaysian rice production. Mitigation and Adaptation Strategies for Global Change, 19, 431-444 https://doiorg/101007/s11027-012-9441-z

Matthews R B, Kropff M J, Horie T, Bachelete D (1997) Simulating the Impact of Climate Change on Rice Production in Asia and Evaluating Options for Adaptation. Agricultural System, 54(3), 399-425 https://doiorg/https://doiorg/101016/S0308-521X(95)00060-I

Mishra D, Chandra N (2016) Impact of climate change on agricultural production of Odisha ( India ): a Ricardian analysis .Regional Environmental Change, 16, 575-584 https://doiorg/101007/s10113-015-0774-5

Mitra S K (2014) Nonlinear impact of rain on foodgrain production in India Applied Economics Letters, 21(14), 1001-1005 https://doiorg/101080/135048512014904483

Mohan R (2006) Agricultural Credit in India Status, Issues and Future Agenda. Economic \& Political Weekly, 41(11), 1013-1023 http://wwwjstorcom/stable/4417965

Mohorji A M, Şen Z, Almazroui M (2017) Trend Analyses Revision and Global Monthly Temperature Innovative Multi-Duration Analysis. Earth Systems and Environment, 1(1), 113 https://doiorg/101007/s41748-017-0014-X

Moore F C, Uris L C, Baldos, Hertel T, 2017. "Economic Impacts of Climate Change on Agriculture: A Comparison of Process-Based and Statistical Yield Models." Environmental Research Letters 12(6)

Moses J A, Jayas D S, Alagusundaram K (2015) Climate Change and its Implications on Stored Food Grains. Agricultural Research, 4(1), 21-30 https://doiorg/101007/s40003-015-0152-z

Mukherjee A, Huda, S A (2018) Assessment of climate variability and trend on wheat productivity in West Bengal, India : crop growth simulation approach. Climate Change, 147, 235-252

Nasrullah, M., Rizwanullah, M., Yu, X., Jo, H., Sohail, M. T., \& Liang, L. (2021). Autoregressive distributed lag (ARDL) approach to study the impact of climate change and other factors on rice production in South Korea.Journal of Water and Climate Change.https://doiorg/102166/wcc2021030. 
Nath H K, Mandal, R (2018) Heterogeneous Climatic Impacts on Agricultural Production: Evidence from Rice Yield in Assam, India Asian Journal of Agriculture and Development, 15 No1, 23-42

Nath P, Behera B (2011) A critical review of the impact of and adaptation to climate change in developed and developing economies Environment, Development and Sustainability, 13, 141-162 https://doiorg/101007/s10668-010-9253-9

Omoregie O K, Ikpesu F, Okpe A E (2018) Credit Supply and Rice Output in Nigeria : Empirical Insight from Vector Error Correction Model Approach International Journal of Economics and Financial Issue, 8(5), 68-74

Pal D, Mitra S K (2018) Asymmetric impact of rainfall on India's foodgrain production : evidence from quantile autoregressive distributed lag model Theoretical Applied Climatology, 131, 6976 https://doiorg/101007/s00704-016-1942-3.

Pathak H, Tripathi R, Jambhulkar N, Bisen J, Panda B (2020) Eco-regional-based Rice Farming for Enhancing Productivity, Profitability and Sustainability In ICAR-National Rice Research Institute (Issue 22)

Pattanayak A, Kumar K S K (2013) Weather Sensitivity of Rice Yield : Evidence from India (Issue September)

Pickson R B, He G, Boateng E (2021) Impacts of climate change on rice production: evidence from 30 Chinese provinces Environment, Development and Sustainability, 0123456789 https://doiorg/101007/s10668-021-01594-8

Praveen B, Sharma, P (2019) A review of literature on climate change and its impacts on agriculture productivity Journal of Public Affairs, 19(4) https://doiorg/101002/pa1960

Praveen B, Sharma, P (2020) Climate Change and its impacts on Indian agriculture: An Econometric analysis Journal of Public Affairs, 20(1) https://doiorg/101002/pa1972

Rayamajhee, Veeshan, Wenmei Guo, and Alok K. Bohara. 2020. “The Impact of Climate Change on Rice Production in Nepal." Economics of Disasters and Climate Change.

Res C, Adams R M, Hurd B H, Lenhart S, \& Leary N (1998) Effects of global climate change on agriculture : an interpretative review 11, 19-30

Sarke M A R, Alam K, Gow J (2019) Performance of rain-fed Aman rice yield in Bangladesh in the presence of climate change Renewable Agriculture and Food Systems, 34(4), 304-312 https://doiorg/101017/S1742170517000473 
Shabbir G, Khaliq T, Ahmad A, Saqib M (2020) Assessing the climate change impacts and adaptation strategies for rice production in Punjab, Pakistan Environmental Science and Pollution Research, 27, 22568-22578

Siddiq E A, Vemireddy L R, Nagaraju J (2012) Basmati Rices: Genetics, Breeding and Trade Agricultural Research, 1(1), 25-36 https://doiorg/101007/s40003-011-0011-5

Swaminathan M S, Kesavan P C (2012) Agricultural Research in an Era of Climate Change Agricultural Research, 1(1), 3-11 https://doiorg/101007/s40003-011-0009-z

Warsame A A, Sheik A I, Ali A O, Sarkodie S A (2021) Climate change and crop production nexus in Somalia: empirical evidence from ARDL technique Environmental Science and Pollution Research, 28(16), 19838-19850 https://doiorg/101007/s11356-020-11739-3

Wassmann R, Jagadish S V K, Sumfleth K, Pathak H, Howell G, Ismail A, Serraj R, Redona E, Singh R K, Heuer S (2009) Chapter 3 Regional Vulnerability of Climate Change Impacts on Asian Rice Production and Scope for Adaptation In Advances in Agronomy (Vol 102, pp 91133) https://doiorg/101016/S0065-2113(09)01003-7

Yuliawan T, Handoko I (2016) The effect of temperature rise to rice crop yield in Indonesia uses Shierary Rice model with geographical information system ( GIS ) feature ProcediaEnvironmental Science, 33, 214-220 https://doiorg/101016/jproenv201603072.

Zakaria A, Alhassan S I, Kuwornu J K M, Azumah S B, Derkyi, M A A (2020) Factors Influencing the Adoption of Climate-Smart Agricultural Technologies Among Rice Farmers in Northern Ghana Earth Systems and Environment, 4(1), 257-271 https://doiorg/101007/s41748-02000146-w 